\title{
A Escola de Salamanca: um caso de produção global de conhecimento*
}

\author{
The School of Salamanca: a case of global knowledge production
}

Thomas Duve**

\section{REFERÊNCIA}

DUVE, Thomas. A Escola de Salamanca: um caso de produção global de conhecimento. Revista da Faculdade de Direito da UFRGS, Porto Alegre, n. 46, p. 3-52, ago. 2021. DOI: https://doi.org/10.22456/01046594.117988.

\section{RESUMO}

Neste artigo, apresento algumas reflexões sobre como conceitualizar o que foi rotulado como "Escola de Salamanca", um movimento intelectual do século XVI e início do século XVII desenvolvido na Universidade de Salamanca. Após reconstruir o desenvolvimento do conceito "Escola de Salamanca" no fim do século XIX e início do século XX, sugiro considerar o movimento intelectual ora discutido sob essa denominação como tanto uma comunidade epistêmica quanto uma comunidade de prática que se estendeu para muito além das fronteiras de Salamanca, Espanha e da Península Ibérica. Mais adequadamente, ela pode ser compreendida como uma parte e um dos centros de uma rede global de produção de conhecimento no campo da normatividade.

\section{PALAVRAS-CHAVE}

Escola de Salamanca. História do Conhecimento. História Global. Teologia Moral. História do Direito. América ibérica. Espanha. Portugal.

\begin{abstract}
In the article, I present some reflections about how to conceptualize what has been labelled the "School of Salamanca", a 16th-and early 17th-century intellectual movement developed at the University of Salamanca. After reconstructing the making of the concept "School of Salamanca" in the late 19th and early 20th century, I suggest to consider the intellectual movement addressed under this denomination as both an epistemic community and a community of practice that reached out far beyond the borders of Salamanca, Spain and the Iberian peninsula. More adequately, it can be understood as a part and one of the centres of a global network of knowledge production in the field of normativity.
\end{abstract}

\section{KEYWORDS}

School of Salamanca. History of Knowledge. Global History. Moral Theology. Legal History. Iberoamerica. Spain. Portugal.

\section{SUMÁRIO}

1 Introdução. 2 Construindo a "Escola de Salamanca". 3 Desconstruindo a "Escola de Salamanca". 4 Construção de sistema e prática diária. 5 Ars Inveniendi. 6 A Escola como uma comunidade epistêmica e uma

\footnotetext{
* A publicação original em língua inglesa teve duas versões, ambas utilizadas aqui. Primeiramente, o texto foi publicado na condição de "working paper": DUVE, Thomas. The School of Salamanca: A Case of Global Knowledge Production. Max Planck Institute for European Legal History Research Paper Series, [s. l.], n. 202012, 2020. Disponível em: $<$ https://ssrn.com/abstract=3627032>. Após, como capítulo de livro: DUVE, Thomas. The School of Salamanca. A Case of Global Knowledge Production. In: DUVE, Thomas; EGÍO, José Luis; BIRR, Christiane (org.). The School of Salamanca: a case of global knowledge production. Leiden; Boston: Brill Nijhoff, 2021. (Max Planck studies in global legal history of the Iberian worlds, v. 2). p. 01-42. Tradução para a língua portuguesa por Gregório Schroder Sliwka (Mestrando em Direito no PPGDir-UFRGS). Revisão por Alfredo de J. Flores (Prof. Permanente PPGDir-UFRGS). A base da tradução partiu do primeiro texto, o que foi autorizado pelo próprio autor, Thomas Duve. A posterior publicação em capítulo de livro pela Editora Brill somente nos serviu de baliza para revisão do texto.

** Professor Doutor de História do Direito em Perspectiva Comparada na Goethe-Universität Frankfurt am Main e membro científico da Sociedade Max Planck desde 2009, ocupando desde 2010 o cargo de diretor no Max Planck Institute for European Legal History (atual Max Planck Institute for Legal History and Legal Theory).
} 
comunidade de prática. 7 Uma perspectiva da história do conhecimento sobre a Escola de Salamanca. 8 Salamanca como um caso de produção global de conhecimento. Referências

\section{INTRODUÇÃO}

O que hoje se conhece como "Escola de Salamanca" surgiu em uma época de transformações políticas, religiosas, econômicas e culturais fundamentais. Muitas dessas transformações estavam ligadas à (proto-)globalização do início da Modernidade e suas consequências: os impérios ibéricos estavam se expandindo e seus territórios rapidamente cobriam o globo. Os europeus encontraram territórios assim como sistemas culturais e políticos que eles não conheciam antes. Ao mesmo tempo, reformas dividiram a res publica christiana, conduzindo a grandes turbulências políticas, guerras e à formação de diferentes culturas confessionais. A revolução midiática permitiu comunicação em velocidades e escalas até então desconhecidas, facilitando acesso ao conhecimento antigo, assim como a uma avalanche de conhecimento novo. Especialmente em função dessas mudanças, repúblicas e monarquias, impérios, ordens religiosas e a Cúria Romana do início da modernidade refinaram suas técnicas de governança. Foi nesse contexto que novas universidades foram fundadas e universidades tradicionais cresceram; a profissionalização aumentou e a ciência floresceu.

A Universidade de Salamanca, fundada em 1218, exerceu um papel chave nesse desenvolvimento, particularmente porque os Reis Católicos a haviam convertido em seu local privilegiado de produção de conhecimento. Em Salamanca, humanistas, juristas, cosmógrafos, teólogos e canonistas treinaram a elite imperial. Aqui, futuros bispos e membros das Audiencias, juristas e missionários estudaram a medição de espaço e tempo, a economia, a linguagem, fé, direito, justiça e injustiça. Os acadêmicos preeminentes daquele tempo vieram a Salamanca para ensinar; casas de publicação estabeleceram suas officinae na cidade; e provavelmente, em poucos lugares no império havia tanta informação sobre explorações e descobrimentos no Caribe e nas Américas - mas também sobre violência, exploração e abusos cometidos pelos invasores europeus - como circulou em Salamanca. Missionários retornavam para sua alma mater; professores universitários vieram da Nova Espanha para publicar seus livros; membros de ordens religiosas poderosas enviaram relatórios aos seus monastérios. A elite castelhana pediu aconselhamento, e uma figura não menos importante que o próprio 
imperador repetidamente consultou acadêmicos de Salamanca para darem sua opinião sobre as questões mais urgentes do momento.

Assim, em Salamanca, mais que em qualquer outro lugar em Castela, informação de diferentes áreas e campos foi coletada, processada e integrada em reflexões teóricas. Enormes tratados foram escritos, que se tornaram objeto de estudo para gerações de estudantes. Muitos deles foram dedicados para questões de direito e justiça. Frequentemente, esses livros viam diferenças edições, eram traduzidos, tinham excertos publicados ou eram condensados em compendia e sumários. Salamanca parecia - e ainda é frequentemente considerada como sinônimo de inovação científica e de produção de conhecimento no Siglo de Oro Español. Não é por acaso, portanto, que nomes como Francisco de Vitoria, Domingo de Soto, Domingo Bañez, Martín de Azpilcueta, Melchior Cano e Francisco Suárez - todos os quais tinham, em algum momento, lecionado em Salamanca - até os dias de hoje encontram-se pars pro toto para um século em que foram formuladas ideias-chave sobre o mundo natural, a economia, a teologia e a filosofia, assim como sobre o direito. A Universidade de Salamanca e sua famosa "Escola de Salamanca" se tornaram parte importante da história da teologia, filosofia, cosmografia, ciências naturais e direito ${ }^{1}$.

\footnotetext{
${ }^{1}$ Há literatura abundante sobre a Escola de Salamanca e seu contexto histórico, e é obviamente impossível listar todos esses trabalhos neste capítulo introdutório. Um estudo introdutório compreensível da Escola com várias referências adicionais sobre o contexto histórico e teológico é: BELDA PLANS, Juan. La escuela de Salamanca y la renovación de la teología en el siglo XVI. Madrid: Biblioteca de Autores Cristianos, 2000. Acadêmicos como Barrientos García, Brufau Prats, Pereña e outros publicaram estudos seminais sobre a Escola de Salamanca e são indispensáveis para toda pesquisa sobre a escola. Para mais referências, ver também três bibliografias extensivas sobre a história da Universidade de Salamanca e a Escola: RODRÍGUEZ-SAN PEDRO BEZARES, Luis E.; POLO RODRÍGUEZ, Juan Luis. Bibliografía sobre la Universidad de Salamanca (1800-2007). In: RODRÍGUEZ-SAN PEDRO BEZARES, Luis Enrique; POLO RODRÍGUEZ, Juan Luis (org.). Historia de la Universidad de Salamanca. Vestigios y entramados. v. 4. 1. ed. Salamanca: Ediciones Universidad de Salamanca, 2002. p. 639-836; PENA GONZÁLEZ, Miguel Anxo. Aproximación bibliográfica a la(s) "Escuela(s) de Salamanca". Salamanca: Universidad Pontifica de Salamanca, 2008; RAMÍREZ SANTOS, Celia Alejandra; EGÍO, José Luis. Conceptos, autores, instituciones: revisión crítica de la investigación reciente sobre la Escuela de Salamanca (2008-19) y bibliografía multidisciplinar (Prefacio de Thomas Duve). Madrid: Editorial Dykinson, 2020. Ramírez e Egío não só provêm uma bibliográfica sistemática e atualizada, mas também incluem uma introdução cuidadosa sobre alguns dos desenvolvimentos da pesquisa nas últimas décadas. Importantes estudos histórico-jurídicos sobre a Escola de Salamanca que fornecem bibliografias específicas sobre tópicos individuais incluem, por exemplo: DECOCK, Wim. Theologians and Contract Law: The Moral Transformation of the Ius Commune (ca. 1500-1650). Leiden: Brill Nijhoff, 2012; GORDLEY, James. The philosophical origins of modern contract doctrine. Oxford; New York: Oxford University Press; Clarendon Press, 1991; JANSEN, Nils. Theologie, Philosophie und Jurisprudenz in der spätscholastischen Lehre von der Restitution. Außer-vertragliche Ausgleichsansprüche im frühneuzeitlichen Naturrechtsdiskurs. Tübingen: Mohr Siebeck, 2013; SCATTOLA, Merio. Krieg des Wissens, Wissen des Krieges: Konflikt, Erfahrung und System der literarischen Gattungen am Beginn der Frühen Neuzeit. Padova: Unipress, 2006. Para uma introdução ao contexto amplo do direito e da moralidade no período do início da modernidade da perspectiva da história do direito, ver: DECOCK, Wim; BIRR, Christiane. Recht und Moral in der Scholastik der Frühen Neuzeit 15001750. Berlin; Boston: De Gruyter, 2016. Disponível em: 〈https://doi.org/10.1515/9783110379686>. Há uma enorme quantidade de literatura sobre o papel de Salamanca na história do pensamento político (com Anthony
} 
Foi a mesma centralidade da Universidade de Salamanca que a converteu em um centro de produção de conhecimento profundamente envolvido com outros lugares. Universidades e seminários na Europa, na América e na Ásia ensinaram de acordo com os métodos e, em alguns casos, seguindo os estatutos de Salamanca. No entanto, como os capítulos $^{(a)}$ de González González, Álvarez Sánchez e Lanza/Tostes neste volume mostram com grande clareza, isso também significava que os métodos de Salamanca não eram simplesmente copiados, mas traduzidos - no sentido amplo de tradução cultural $^{2}$ - para realidades locais em continentes diferentes. No mesmo sentido, no México, Manila e em outros lugares, excertos, cópias, rescritos, novos manuscritos e livros impressos que se baseavam em ideias e práticas oriundas de Salamanca foram produzidos, mas criaram também algo novo. Em última análise, esses atores foram convencidos de que - malgrado a diferença de locais e situações em que eles viviam - todos estavam sujeitos a princípios universais, contribuíam para suas realizações ao colocar esses princípios em prática sob uma variedade de condições locais, e compartilhavam um consenso básico sobre como proceder em fazendo dessa forma. Os capítulos de Folch, Cobo, Moutin, Camacho, Egío e Aspe Armella

Pagden e Annabel Brett como pontos de referência centrais), da política imperial, do direito internacional, dos direitos humanos, das discussões sobre os direitos dos povos indígenas e crescentemente também sobre Salamanca e escravidão. Também a 'virada histórica do direito internacional' iniciada por Martti Koskenniemi levou a uma onda de novas publicações sobre a Escola, com a maioria se concentrando sobre a história do 'redescobrimento' da Escola no século XIX e sua significância para o direito internacional. Importantes insights sobre as fundações morais do direito e da política no início da modernidade foram alcançados através dos trabalhos de Paolo Prodi, Adriano Prosperi e outros os seguindo. Embora eles não se concentrem exclusivamente na Escola de Salamanca, eles revelam a importância da teologia moral e sua prática para o mundo católico do início da modernidade. Desde o fim da década de 1970, historiadores do direito espanhóis como Jesús Lalinde Abadía e Bartolomé Clavero nos conscientizaram sobre a importância da religião na história do direito do início da Modernidade e seus contextos coloniais. Uma coleção recente sobre pensamento político e social no início da Modernidade, com contribuições sobre direito colonial e outros aspectos foi agora apresentada por: TELLKAMP, Jörg Alejandro (org.). A Companion to Early Modern Spanish Imperial Political and Social Thought. Leiden; Boston: Brill, 2020; e um companion sobre a Escola de Salamanca está sendo preparado por: BRAUN, Harald E.; ASTORRI, Paolo (org.). A Companion to the Spanish Scholastics. Leiden: Brill, [no prelo]. Para um levantamento geral da história do período, ver agora: BOUZA ALVAREZ, Fernando J.; CARDIM, Pedro; FEROS, Antonio (org.). The Iberian world 1450-1820. New York: Routledge, 2020; BARRETO XAVIER, Ângela; PALOMO, Federico; STUMPF, Roberta Giannubilo (org.). Monarquias ibéricas em perspectiva comparada (séculos XVI-XVIII): dinâmicas imperiais e circulação de modelos políticoadministrativos. Lisboa, Portugal: Imprensa de Ciências Sociais, 2018.

(a) Nota de tradução: uma vez que este texto é o capítulo inicial de um livro coletivo, a referência aqui aos demais capítulos remete aos mesmos na publicação: DUVE, Thomas; EGÍO, José Luis; BIRR, Christiane (org.). The School of Salamanca: a case of global knowledge production. Leiden; Boston: Brill Nijhoff, 2021.

${ }^{2}$ Neste artigo, o termo "tradução cultural" é usado no sentido amplo que ele adquiriu nos estudos culturais. Para uma discussão completa sobre o tema: DUVE, Thomas. Pragmatic Normative Literature and the Production of Normative Knowledge in the Early Modern Iberian Empires (16th-17th Centuries). In: DUVE, Thomas; DANWERTH, Otto (org.). Knowledge of the Pragmatici: Legal and Moral Theological Literature and the Formation of Early Modern Ibero-America. Leiden: Brill | Nijhoff, 2020. p. 01-39. Disponível em: <https://doi.org/10.1163/9789004425736_002>. 
apresentam estudos de caso sobre como atores negociavam as tensões entre universalidade e localização na Nova Espanha, nas Filipinas e no contexto de contato com a China, respectivamente. Alguns dos livros escritos no Novo Mundo eram impressos, lidos e comentados em Salamanca, e, assim, levantavam novas deliberações na universidade e no monastério de San Esteban. As cartas que os professores recebiam de seus antigos estudantes, agora servindo na América e na Ásia ibérica, e as estórias que eles contavam quando retornavam para Salamanca, continham ricas informações e levantavam questões que os teólogos tentavam responder em suas aulas e em seus tratados. Em outras palavras, a comunicação não era unidirecional: o conhecimento circulava e era continuamente reformatado. Salamanca era um importante nódulo nessa enorme rede de locais em que o conhecimento normativo era produzido ${ }^{3}$. É essa perspectiva global sobre a produção de conhecimento nos mundos ibéricos que este livro quer explorar ${ }^{4}$.

Conhecimento normativo, no entanto, não é só sobre teoria, ideias, princípios ou doutrinas: ele também inclui práticas. Ele é, como foi expresso para um contexto moderno,

\footnotetext{
${ }^{3}$ Dentro do extensivo debate sobre "informação" e "conhecimento" e suas respectivas definições, optei por uma distinção entre os termos que concebem a informação como unidade básica, como dado com relevância e propósito gerais. Informação é convertida em conhecimento assim que é contextualizada e integrada em um campo de ação, abrindo possiblidades para ação. Conhecimento pode, então, ser entendido como uma totalidade de proposições que membros de um grupo consideram ser verdadeiras ou que são consideradas verdadeiras em uma quantidade suficiente de textos produzidos por membros desse grupo, compreendendo todos os tipos de padrão de pensamento, orientação e ação. Ele compreende também conhecimento implícito enraizado nas práticas e rotinas organizacionais; sobre as diferentes definições, ver, por exemplo: NEUMANN, Birigt. Kulturelles Wissen. In: NÜNNING, Ansgar (org.). Metzler Lexikon Literatur- und Kulturtheorie: AnsätzePersonen-Grundbegriffe. 5. ed. Stuttgart; Weimar: Springer, 2013, p. 811; WEHLING, Peter. Wissensregime. In: SCHÜTZEICHEL, Rainer (org.). Handbuch Wissenssoziologie und Wissensforschung. Konstanz: UVK, 2007. p. 704-712. Minha definição é mais restrita que a utilizada por Renn e Hyman [RENN, Jürgen; HYMAN, Malcolm $\mathrm{H}$. The Globalization of Knowledge in History: An Introduction. in: RENN, Jürgen (ed.). The Globalization of Knowledge in History. Berlin: Edition Open Access, 2012. p. 15-44. Disponível em: <http://www.edition-openaccess.de/media/studies/1/5/Studies1ch1.pdf $>$. esp. p. 21-22], que definem conhecimento como a capacidade de um indivíduo, grupo ou sociedade para resolver problemas e de antecipar mentalmente a ação necessária; eles provêm uma interessante lista de formas de representação de conhecimento e formas de transmissão. Para um panorama sistemático, ver também: ABEL, Günter. Systematic Knowledge Research. Rethinking Epistemology. In: SANDKÜHLER, Hans Jörg (Ed.). Wissen: Wissenskulturen und die Kontextualität des Wissens, Frankfurt: Peter Lang, 2014. p. 17-37. Na discussão que segue, conhecimento "normativo" refere-se ao conhecimento como "possibilidades positivamente afirmadas", uma definição desenvolvida por Christoph Möllers (MÖLLERS, Christoph. Die Möglichkeit der Normen. Über eine Praxis jenseits von Moralität und Kausalität. Berlin: Suhrkamp, 2015). Sobre esses aspectos, ver: DUVE, Thomas. Pragmatic Normative Literature and the Production of Normative Knowledge in the Early Modern Iberian Empires (16th-17th Centuries). In: DUVE, Thomas; DANWERTH, Otto (org.). Knowledge of the Pragmatici: Legal and Moral Theological Literature and the Formation of Early Modern Ibero-America. Leiden: Brill | Nijhoff, 2020. p. 01-39. Disponível em: <https://doi.org/10.1163/9789004425736_002>.

${ }^{4}$ Para as ideias implícitas no projeto deste livro, ver o working paper enviado aos autores convidados para participar e discutir suas contribuições em um workshop sediado em Buenos Aires em 2018: DUVE, Thomas. La Escuela de Salamanca: ¿un caso de producción global de conocimiento? consideraciones introductorias desde una perspectiva histórico-jurídica y de la historia del conocimiento. The School of Salamanca Working Paper Series, Frankfurt am Main, n. 2018-2, 2018.
} 
uma atividade da mente, uma forma de fazer algo com as regras e casos e outros materiais do direito, uma atividade que é ela mesma não redutível a um conjunto de orientações ou qualquer descrição fixa. É uma espécie de competência cultural, como aprender uma linguagem. 5

O mesmo se aplica - em um grau ainda maior - para o mundo do início da Modernidade, razão pela qual foi o modo de raciocínio ensinado e praticado em Salamanca, e a maneira pela qual casos concretos eram resolvidos de acordo com ele, que moldou a forma pela qual a justiça era administrada em vários locais. Onde quer que um missionário, um padre, um bispo, mas também um juiz, ou um oficial da Coroa que tivesse estudado em Salamanca ou lido livros de lá, exercesse seu ofício, ele produzia novas afirmações normativas [normative statements] com base no que ele havia aprendido em ou de Salamanca. As análises de coleções de decisões de corpos judiciais, declarações de bispos, práticas de ensino ou a escrita de opiniões em problemas centrais da vida colonial (como casamento, restituição e guerra justa) nas contribuições de Aspe Armella, Camacho, Cobo, Egío, Folch, Moutin e Lanza/Toste, respectivamente, apontam para esses contextos pragmáticos de produção de conhecimento normativo. Ou seja - como esse capítulo introdutório objetiva destacar -, a combinação do desenvolvimento intelectual e científico dinâmico da Escola e seu caráter essencialmente pragmático, mirando a cura animarum, central para entender a Escola. Pode ter sido precisamente essa combinação de teoria e prática, independentemente de vermos a Escola como parte de um imperialismo jurídico opressor ou como os inícios de um

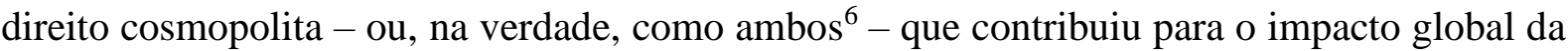
Escola de Salamanca sobre a formação de uma linguagem de normatividade e de práticas normativas.

Essa presença e translação global de conhecimento normativo que foi desenvolvido em Salamanca, a interconectividade entre Salamanca e outro locais e as orientações pragmáticas de seu(s) método(s) de raciocínio levantam questões importantes.

\footnotetext{
${ }^{5}$ WHITE, James Boyd. Legal Knowledge. Harvard Law Review, vol. 115, n. 5, 2002, p. 1396-1431. Disponível em: <https://doi.org/10.2307/1342550>. p. 1399.

${ }^{6}$ A significância da linguagem política é enfatizada tanto por acadêmicos que destacam a contribuição de Salamanca para o direito internacional de uma maneira mais defensiva - em alguns casos até hagiográfica quanto por aqueles que tomam uma perspectiva mais crítica. Para uma abordagem balanceada, ver: KOSKENNIEMI, Martti. Empire and International Law: The Real Spanish Contribution. University of Toronto Law Journal, [s. l.], v. 61, n. 1, p. 1-36, 2011. Disponível em: 〈https://doi.org/10.1353/tlj.2011.0008>.
} 
Primeiro, elas nos fazem pensar sobre quais podem ser os critérios definidores da "Escola de Salamanca", e sobre como decidir quem deveria ser considerado membro da Escola, especialmente em termos geográficos. Deveriam ser só aqueles que aprenderam ou ensinaram teologia tomista em Salamanca, como alguns acadêmicos sustentam? No entanto, se se restringe a Escola geograficamente a Salamanca, como se deveria classificar o trabalho feito em Coimbra e em Évora? Seria Martín de Azpilcueta, que escreveu seu bem-sucedido Manual de Confessores primeiro em Coimbra (para onde ele havia sido enviado desde Salamanca) considerado um membro da Escola? E como se deveria classificar o que era ensinado e escrito em Manila ou no México, ou em seminários e colégios em Córdoba del Tucumán, por acadêmicos que haviam estudado em Salamanca e depois aplicaram o que haviam aprendido? Ou os ensinamentos e escritos daqueles que nunca tocaram solo castelhano, mas estavam profundamente imersos no modo de pensar ao estilo de Salamanca e o colocavam em prática? Os capítulos neste volume mostram que existem boas razões para integrá-los em uma análise conjunta com aqueles autores "espanhóis" tradicionalmente considerados membros da Escola.

E por que razão - para levantar questões adicionais resultantes da orientação pragmática da teologia moral do início da Modernidade, como era praticada em Salamanca nós definimos a Escola como um grupo de autores, e não como uma comunidade de práticas? Por que nós não incluímos seus julgamentos em casos individuais, tanto no forum externum quanto no forum internum, ou suas opiniões e conselhos práticos, no conjunto de fontes que constituem a Escola? Qual ideia da Escola de Salamanca subjaz ante a concentração quase exclusiva da historiografia nos grandes tratados sistemáticos, e a negligência geral aos vários pequenos livros e à literatura pragmática? Salamanca não se tornou famosa precisamente em razão de suas deliberações sobre problemas práticos, como a legitimidade da conquista ou os poderes respectivos do Papa e do Imperador? Ela não se tornou influente em função dos milhares de atos de produzir uma afirmação normativa [normative statements] - um julgamento, uma opinião, um cânone em um Concílio da Igreja - que eram pronunciados de acordo com os ensinamentos e as práticas aprendidas em Salamanca e em outros lugares?

Enquanto algumas dessas questões tenham sido intensamente discutidas, surpreendentemente poucas delas foram objeto de reflexão crítica ${ }^{7}$. No entanto, por trás delas

\footnotetext{
${ }^{7}$ A definição da escola é há muito objeto de debate acadêmico. Ver, por exemplo: BELDA PLANS, Juan. La escuela de Salamanca y la renovación de la teología en el siglo XVI. Madrid: Biblioteca de Autores Cristianos, 2000. p. 147-206; BELDA PLANS, Juan. Hacia una noción crítica de la "Escuela de Salamanca". Scripta
} 
está um problema geral que é importante para o estudo da Escola de Salamanca, mas que também vai muito além dela: o dilema de como analisar e classificar um fenômeno intelectual como a "Escola de Salamanca", que foi culturalmente traduzido sob as condições da expansão europeia e da revolução midiática em muitos locais ao redor de todo o mundo. A sugestão feita neste capítulo é entender a Escola de Salamanca não como um grupo de autores em um local, mas como a denominação de um modo específico de produzir conhecimento normativo, como um processo comunicativo que era performado por uma multitude de atores. Colocado de modo simples, a "Escola de Salamanca" não era um grupo de autores, mas uma prática cultural, um modo específico de participar em um sistema comunicativo dedicado à normatividade ${ }^{8}$.

Para demonstrar isso, não vou começar com as premissas teóricas e metodológicas subjacentes a essa perspectiva ${ }^{9}$, mas em vez disso vou me concentrar sobre os autores

theologica, [s. l.], v. 31, n. 2, p. 367-411, 1999; BARRIENTOS GARCÍA, José. La teología, siglos XVI-XVII. In: RODRÍGUEZ-SAN PEDRO BEZARES, Luis Enrique (org.). Historia de la Universidad de Salamanca. v. 3/1. 1. ed. Salamanca: Ediciones Universidad de Salamanca, 2002; BARRIENTOS GARCÍA, José. La escuela de Salamanca: desarrollo y caracteres. Ciudad de Dios: Revista agustiniana, [s. l.], v. 208, n. 2-3, p. 1041-1079, 1995; BERMEJO, Ignacio Jericó. ¿Escuela de Salamanca y Pensamiento hispánico?: Ante una propuesta. Salmanticensis, [s. l.], v. 59, n. 1, p. 83-114, 2012; BRUFAU PRATS, Jaime. La Escuela de Salamanca ante el descubrimiento del Nuevo Mundo. Salamanca: Editorial San Esteban, 1989. p. 123-124; ZORROZA HUARTE, Maria Idoya. Hacia una delimitación de la Escuela de Salamanca. Revista Empresa y Humanismo, [s. l.], v. XVI, n. 1, p. 53-72, 2013; MARTÍN GÓMEZ, María. Francisco de Vitoria y la Escuela Ibérica de la Paz. Revista Portuguesa de Filosofia, [s. l.], v. 75, n. 2, p. 861-890, 2019. Disponível em: <https://doi.org/10.17990/RPF/2019_75_2_0861>.

${ }^{8}$ Sobre a necessidade de abrir o conceito centrado-no-Estado e legalista de "direito" para incluir outras esferas normativas, ver: DUVE, Thomas. Von der Europäischen Rechtsgeschichte zu einer Rechtsgeschichte Europas in globalhistorischer Perspektive. Rechtsgeschichte - Legal History, [s. l.], n. 20, p. 71, 2012. Disponível em: <https://doi.org/10.12946/rg20/018-071>; DUVE, Thomas. Was ist >Multinormativität<? - Einführende Bemerkungen. Rechtsgeschichte - Legal History, [s. l.], n. 25, p. 88-101, 2017. Disponível em: <https://doi.org/10.12946/rg25/088-101>; DUVE, Thomas. Global Legal History: Setting Europe in Perspective. In: PIHLAJAMÄKI, Heikki; DUBBER, Markus D.; GODFREY, Mark (org.). The Oxford Handbook of European Legal History. Oxford; New York: Oxford University Press, 2018. p. 115-140. Disponível em: <https://doi.org/10.1093/oxfordhb/9780198785521.013.5>.

${ }^{9}$ As premissas metodológicas subjacentes a essa perspectiva são desenvolvidas em um diálogo entre o ainda emergente campo da histórica do conhecimento e as abordagens teórico-jurídicas que compreendem o direito como um sistema comunicativo. Para uma introdução geral à história do conhecimento e para referências complementares, ver: BURKE, Peter. What is the history of knowledge? Cambridge: Polity, 2016. Uma boa introdução ao atual estado de pesquisa no campo é oferecido por: RENN, Jürgen. From the History of Science to the History of Knowledge - and Back. Centaurus, vol. 57, n. 1, 2015, p. 37-53. Disponível em: <https://doi.org/10.1111/1600-0498.12075>; DASTON, Lorraine. The History of Science and the History of Knowledge. Know, [s. l.], v. 1, n. 1, p. 131-154, 2017. Disponível em: <https://doi.org/10.1086/691678>; MÜLLER-WILlE, Staffan; REINHARDT, Carsten; SOMMER, Marianne. Wissenschaftsgeschichte und Wissensgeschichte. In: MÜLLER-WILLE, Staffan et al. (org.). Handbuch Wissensgeschichte. Stuttgart: J. B. Metzler, 2017. p. 02-18. Sobre a globalização do conhecimento, ver: RENN, Jürgen (ed.). The Globalization of Knowledge in History. Berlin: Edition Open Access, 2012. Disponível em: <http://edition-openaccess.de/studies/1/index.html>); e, especialmente: RENN, Jürgen; HYMAN, Malcolm H. The Globalization of Knowledge in History: An Introduction. in: RENN, Jürgen (Ed.). The Globalization of Knowledge in History. 
clássicos, os textos da Escola e a historiografia sobre ela de forma a mostrar como, na Escola de Salamanca, teoria, orientação pragmática e uma certa forma de agir, entendida como "práticas" em um sentido praxiológico, estavam inseparadamente entrelaçadas $(4,5)$. Por essa razão, a Escola pode ser vista como uma comunidade epistêmica e como uma comunidade de prática, caracterizada por um modo específico de produzir conhecimento normativo (6). A perspectiva histórica do conhecimento tomada por esta abordagem também nos permite compreender a Escola de Salamanca como um caso de produção global de conhecimento, deslocando nossa atenção para fora de suas supostas origens, autores e locais, para compreendê-la e analisá-la como uma esfera do processo multidirecional e complexo de comunicação sobre normatividade no período do início da Modernidade $(7,8)$. Antes de abordar esses temas, no entanto, parece necessário questionar como a noção da "Escola de Salamanca" surgiu e o que esse termo significava quando foi utilizado pela primeira vez, bem como as dependências estruturais que poderiam ter resultado dessa compreensão inicial da Escola $(2,3)$.

\section{CONSTRUINDO A "ESCOLA DE SALAMANCA"}

Sem objetivar reconstruir o desenvolvimento completo da historiografia sobre a Escola de Salamanca ${ }^{10}$, parece importante enfatizar que, mesmo que os estudantes imediatos de Vitoria já o reconhecessem como seu professor e claramente tivessem a ideia de

Berlin: Edition Open Access, 2012. p. 15-44. Disponível em: <http://www.edition-openaccess.de/media/studies/1/5/Studies1ch1.pdf >. Sobre o potencial para um diálogo frutífero entre a história do direito global e a história do conhecimento, ver: RENN, Jürgen. The Globalization of Knowledge in History and its Normative Challenges. Rechtsgeschichte - Legal History, vol. 22, p. 52-60, 2014. Disponível em: $<$ https://doi.org/10.12946/rg22/052-060>. As premissas metodológicas subjacentes à análise apresentada aqui são próximas - e em verdade muito devem - ao trabalho de A. M. Hespanha, ver: HESPANHA, António. Southern Europe (Italy, Iberian Peninsula, France). In: PIHLAJAMÄKI, Heikki; DUBBER, Markus D.; GODFREY, Mark (org.). The Oxford Handbook of European Legal History. Oxford: Oxford University Press, 2018. p. 332-356. Disponível em: <https://doi.org/10.1093/oxfordhb/9780198785521.013.17>. A combinação do conceito de tradução com uma perspectiva evolutiva apresentada aqui foi inspirada especialmente pelos escritos de H. P. Glenn e sua conceitualização de "tradição jurídica"; ver, sobre isso mais extensivamente: DUVE, Thomas. Legal traditions: A dialogue between comparative law and comparative legal history. Comparative Legal History, $[s . \quad$ l. $], \quad$ v. $6, \quad$ n. $1, \quad$ p. $15-33, \quad 2018$. Disponível em: <https://doi.org/10.1080/2049677X.2018.1469271>.

${ }^{10}$ Para uma discussão mais detalhada, ver: DUVE, Thomas. The School of Salamanca: a legal historical perspective. In: BRAUN, Harald E.; ASTORRI, Paolo (org.). A Companion to the Spanish Scholastics. Leiden: Brill, [no prelo]. 
pertencimento a uma escola"11, foi apenas no fim do século XIX que o termo "Escola de Salamanca" foi cunhado e veio para ser apresentado como um importante momento na história do pensamento jurídico e político europeu, com Francisco de Vitoria como seu mais importante representante, e o direito internacional como seu mais famoso objeto. As razões para essa redescoberta são diversas ${ }^{12}$. O renascimento de Vitoria na Espanha no fim do século XIX foi parte de uma tentativa de enfatizar a contribuição espanhola para o desenvolvimento da ciência europeia. Foi Eduardo Hinojosa y Naveros, frequentemente considerado o pai fundador da história do direito espanhola, que, na ocasião de sua admissão à Real Academia de la Historia em Madri em 1889 - introduzido por Marcelino Menéndez y Pelayo, o famoso autor de La Ciencia Española -, deu uma conferência pública sobre a significância de Francisco de Vitoria para a emergência do direito internacional enquanto disciplina acadêmica $^{13}$. Esse novo campo viu uma evolução marcantemente dinâmica durante a década de 1880 e foi de suma importância para a Espanha, onde novas cátedras universitárias, periódicos e institutos para a disciplina emergente estavam sendo fundados, também em razão da necessidade de melhor compreender a posição da Espanha nos recentes e ainda correntes conflitos com e entre suas antigas colônias e outras potências europeias. Em sua apresentação na Academia, Hinojosa destacou uma série de aspectos do trabalho de Vitoria, em particular o que ele chamou de método científico positivo de Vitoria, a fundação do pensamento jurídico de Vitoria nos ensinamentos de Tomás de Aquino e sua unidade entre estudos jurídicos e teológicos. Para Hinojosa, estudar Francisco de Vitoria significava chamar atenção à contribuição espanhola para a herança cultural europeia, em resposta àqueles que, de acordo com Hinojosa, continuavam negando à Espanha seu papel devido nessa história ${ }^{14}$.

\footnotetext{
${ }^{11}$ Ver, por exemplo, como Melchior Cano cria a ideia de ser parte de uma escola liderada por Vitoria: CANO, Melchor. De locis Theologicis. Salamanca: Mathias Gast, 1563, Liber duodecimus, Prooemium, fol. 385: "Fratrem Franciscum Victoria [...] dicere audivi postqua[m] ab illi[us] schola discessi [...]".

${ }^{12}$ Sobre a história da historiografia e para referências adicionais, ver: DUVE, Thomas. Rechtsgeschichte und Rechtsräume: wie weit reicht die Schule von Salamanca? In: LUTS-SOOTAK, Marju; SCHÄFER, Frank L. (org.). Recht und Wirtschaft in Stadt und Land - Law and Economics in Urban and Rural Environment. Neunter Rechtshistorikertag im Ostseeraum/9th Conference in Legal History in the Baltic Sea Area 16.-20. Mai 2018 in Tallinn, Sagadi und Tartu, Estland/ in Tallinn, Sagadi and Tartu, Estonia. Bern: Peter Lang, 2020. p. 51-72. Disponível em: <https://doi.org/10.3726/b16496>.

${ }^{13}$ HINOJOSA Y NAVEROS, Eduardo de. Discursos leídos ante la Real Academia de la Historia en la recepción pública de D. Eduardo de Hinojosa el día 10 de marzo de 1889. Madrid: Huérfanos, 1889. Sobre Hinojosa, ver agora: MARTÍNEZ NEIRA, Manuel; RAMÍREZ JÉREZ, Pablo. Hinojosa en la Real Academia de Ciencias Morales y Políticas. Madrid: Dykinson, 2018 - que inclui texto de Hinojosa: Influencia que tuvieron en el derecho público de su patria y singularmente en el derecho penal los filósofos y teólogos españoles anteriores a nuestro siglo (1890), p. 105-226.

${ }^{14}$ HINOJOSA Y NAVEROS, Eduardo de. Discursos leídos ante la Real Academia de la Historia en la recepción pública de D. Eduardo de Hinojosa el día 10 de marzo de 1889. Madrid: Huérfanos, 1889, p. 52.
} 
Com sua tentativa de realçar Vitoria como o "pai do direito internacional" - como ele foi explicitamente chamado por Menéndez y Pelayo na mesma ocasião -, Hinojosa era parte de um movimento mais amplo buscando as fundações históricas do direito internacional e que estava ocorrendo não apenas na Espanha ${ }^{15}$. Mais e mais juristas, também fora da Espanha, apontavam o papel vital dos teólogos salmantinos na história da disciplina como predecessores de Hugo Grotius. O acadêmico belga Ernest Nys o fez a partir do início da década de 1880 e, mais de três décadas depois, publicou o famoso Relectiones de Vitoria em $1917^{16}$. Nos EUA, James Brown Scott produziu uma tradução inglesa de De Indis recenter inventis e De iure belli de Francisco de Vitoria em 1917, e seguindo outros estudos, publicou sua monografia, The Spanish Origin of International Law. Francisco de Vitoria and his Law of Nations, em $1932^{17}$. Acadêmicos da teologia e da filosofia contribuíram com uma série de estudos sobre Vitoria para essa primeira renascença, também no contexto da Neoescolástica espanhola. Assim, Luis G. Alonso Getino publicou vários fragmentos no periódico La Ciencia Tomista, que havia sido fundado em 1914, e alguns de seus escritos foram posteriormente integrados em uma nova série, Biblioteca internacionalista Francisco de Vitoria $^{18}$. Foi nesse contexto geral, e mais especificamente nas tentativas de refundar o tomismo filosófico e teológico, que o termo "Escola de Salamanca" parece ter sido primeiramente empregado $^{19}$.

\footnotetext{
${ }^{15}$ Ver em geral sobre esse período: KOSKENNIEMI, Martti. The gentle civilizer of nations: the rise and fall of international law, 1870-1960. Cambridge: Cambridge University Press, 2002. Para o contexto espanhol, ver: RASILLA DEL MORAL, Ignacio de la. In the Shadow of Vitoria: A History of International Law in Spain (1770-1953). Leiden: Brill Nijhoff, 2017.

${ }^{16}$ NYS, Ernest. Le droit de la guerre et les précurseurs de Grotius. Bruxelles; Leipzig; Londres; New York; Paris: Librairie Européenne C. Muquardt, Merzbach et Falk; Trübner \& Co; Durand et Pedone Lauriel, 1882.

${ }^{17}$ SCOTT, James Brown. The Catholic Conception of International Law. Francisco de Vitoria, Founder of the Modern Law of Nations. Francisco Suarez, Founder of the Modern Philosophy of Law in General and in Particular of the Laws of Nations. A Critical Examination and a Justified Appreciation. Washington D. C.: Georgetown University Press, 1934; SCOTT, James Brown. The Spanish Origin of International Law. Francisco de Vitoria and his Law of Nations. Oxford: Clarendon Press, 1934. Sobre Scott, ver: SCARFI, Juan Pablo. The hidden history of international law in the Americas: empire and legal networks. New York, NY: Oxford University Press, 2017.

${ }^{18}$ ALONSO GETINO, Luis G. El Maestro Fr. Francisco de Vitoria. Su vida, su doctrina e influencia. Madrid: Imprenta Católica, 1930.

${ }^{19}$ O teólogo alemão Martin Grabmann parece ter sido o primeiro a usar o termo "Escola de Salamanca" em um ensaio publicado em 1917, que comemorava o $300^{\circ}$ aniversário da morte de Francisco Suárez [GRABMANN, Martin. Die Disputationes metaphysicae des Franz Suarez in ihrer methodischen Eigenart und Fortwirkung. In: SIX, Karl et al. (org.). P. Franz Suarez S.J.: Gedenkblätter zu seinem dreihundertjährigen Todestag (25. September 1917). Beiträge zur Philosophie des P. Suarez. Innsbruck: Tyrolia, 1917, p. 29-73]. Ele recorreu a pesquisas anteriores feitas pelo jesuíta alemão Ehrle na biblioteca do Vaticano. No ensaio de Grabmann, o termo "Theologenschule zu Salamanca" ("escola de teólogos em Salamanca") primeiro aparece em uma nota de rodapé; posteriormente, no texto ele refere-se a estudos sobre a "Escola de Salamanca e sobre o escolasticismo espanhol e português". O termo foi posteriormente usado no contexto da história econômica, ver: GRICE-
} 
Obviamente, esse engajamento com Vitoria e a Escola de Salamanca era também parte de discussões mais amplas sobre o direito internacional que se intensificaram durante e após a Primeira Guerra Mundial, assim como dos movimentos panamericanos e suas buscas por fundações intelectuais, que estavam ganhando força desde 1900. Ele foi acompanhado por pesquisa sobre o humanismo espanhol, e pela história do escolasticismo espanhol definida amplamente, que floresceu no período entreguerras: em Paris, o Erasme et l'Espagne de Marcel Bataillon em $1937^{20}$, e em Roma, um ano depois, o La Universidade de París durante los estudios de Francisco de Vitoria. Em Salamanca, importante edições de fontes foram preparadas, em primeiro lugar por Vicente Beltrán de Heredia, que, de 1932 em diante, começou a publicar as notas de estudantes sobre as conferências ordinárias de Vitoria sobre a Summa ${ }^{21}$. Uma pequena monografia biográfica e bibliográfica de 1939 sobre Vitoria escrita por Beltrán de Heredia, o principal acadêmico sobre a Escola naqueles tempos turbulentos, se tornou um importante ponto de referência. O fato desse estudo ter aparecido como volume 14 na Colección pro ecclesia et patria aponta para o teor de muitas pesquisas sobre Francisco de Vitoria e a Escola de Salamanca durante o período de Franco.

Várias dessas publicações se concentraram em destacar a contribuição de autores espanhóis para o estabelecimento de um direito internacional que visava prover paz (uma série de publicações é até chamada 'Corpus Hispanorum de Pace') e espalhar valores cristãos em um mundo em que o Hispanismo havia exercido e deveria exercer um papel importante ${ }^{22}$. De certa forma, vários autores ainda lutavam contra a assim chamada "Leyenda Negra", mesmo que agora sob circunstâncias políticas diferentes ${ }^{23}$. Autores de Salamanca tomaram a liderança nesse processo, vários deles experts na história da universidade e na história da ordem dominicana espanhola, e alguns - como Betrán de Heredía - eram eles próprios

\footnotetext{
HUTCHINSON, Marjorie. El concepto de la Escuela de Salamanca: sus orígenes y su desarrollo. Revista de Historia Económica, [s. l.], v. 7, $\quad$ n. $\quad$ S1, p. 21-26, 1989. Disponível em: <https://doi.org/10.1017/S0212610900001798>.

${ }^{20}$ BATAILLON, Marcel. Erasme et l'Espagne. Recherches sur l'histoire spirituelle du XVIe siècle. Paris, Bordeaux: E. Droz, 1937.

${ }^{21}$ Sobre os manuscritos, ver: BELTRÁN DE HEREDIA, Vicente. Los manuscritos del maestro fray Francisco de Vitoria, O.P. Madrid: Santo Domingo el Real, 1928.

${ }^{22}$ Para uma discussão a partir da perspectiva da história das universidades, ver Gonzaléz neste volume. Uma certa tendência apologética ainda é visível nos títulos de grandes publicações, inclusive aquela da série de publicações Corpus Hispanorum de Pace; uma seleção de ensaios que desenvolve essa perspectiva pode ser encontrada em: RAMOS, Demetrio (org.). Francisco de Vitoria y la Escuela de Salamanca: La ética en la Conquista de América. Madrid: Consejo Superior de Investigaciones Científicas, 1984.

${ }^{23}$ Ver sobre isso agora as contribuições em: VILLAVERDE RICO, María José; CASTILLA URBANO, Francisco (org.). La sombra de la leyenda negra. Madrid: Tecnos, 2016.
} 
membros dessa ordem. Não era, portanto, surpreendente que a maioria da pesquisa se concentrasse em Salamanca e nos Dominicanos, inclusive porque os arquivos em Salamanca continham (e ainda contêm) vastas quantidades de documentação por explorar. Esses acadêmicos viam Salamanca como o centro que exercia sua influência sobre vários locais ao redor do mundo 24 .

\section{DESCONSTRUINDO A "ESCOLA DE SALAMANCA"}

Olhando para este cenário, e não obstante as inevitáveis generalizações, nós podemos dizer que a narrativa dominante desde a década de 1880 até o fim do regime de Franco colocou Francisco de Vitoria na fundação de um movimento intelectual cuja localização exclusiva havia sido Salamanca, e que havia sido profundamente científico, dominicano e espanhol. Para a maioria dos pesquisadores durante o primeiro século do renascimento de Vitoria, e até para alguns hoje, a maior conquista da Escola reside em sua contribuição para a formação de uma ciência do direito internacional e em uma renovação da teologia (moral), baseada em uma união particular da nação espanhola, da fé cristã, e da teologia e filosofia tomista. A Escola era composta de autores, tinha um centro, e influenciou a periferia.

De uma perspectiva historiográfica jurídica, a apresentação feita por Hinojosa e seus contemporâneos de que Vitoria seria o pai fundador do direito internacional, e por isso uma grande contribuição espanhola para a história dos estudos jurídicos europeus, era uma forma de integrar a Escola em uma grande narrativa da história do direito europeu como uma história de cientifização (Verwissenschaftlichung) - uma narrativa histórica sobre a história do direito europeu fazendo remissão à Escola Histórica do Direito que Hinojosa estudou extensivamente quando esteve na Alemanha e que depois levou com ele para a Espanha. Particularmente na pesquisa histórico-jurídica de língua alemã do século XX, a Escola de Salamanca começou - depois de algum trabalho inicial de Josef Kohler ${ }^{25}$ - a ser estudada

\footnotetext{
${ }^{24}$ Tem havido um número crescente de estudos sobre o que se chama de proyección Americana de Salamanca; ver, por exemplo: CEREZO, Prometeo. Influencia de la Escuela de Salamanca en el pensamiento universitario americano. In: RAMOS, Demetrio et al. (org.). La ética de la conquista de América. Madrid: Consejo Superior de Investigaciones Científicas, 1984. p. 551-596. Sobre a proyección, ver também: BARRIENTOS GARCÍA, José. Repertorio de moral económica, 1526-1670: la Escuela de Salamanca y su proyección. 1. ed. Pamplona: Eunsa, 2011, p. 77-84; RODRÍGUEZ-SAN PEDRO BEZARES, Luis Enrique; POLO RODRÍGUEZ, Juan Luis (org.). La Universidad de Salamanca y sus confluencias americanas. Salamanca: Universidad de Salamanca, 2008.

${ }^{25}$ KOHLER, Josef. Die spanischen Naturrechtslehrer des 16. und 17. Jahrhunderts. Archiv für Rechts- und Wirtschaftsphilosophie, [s. l.], v. 10, n. 3, p. 235-263, 1917.
} 
mais intensivamente sob a influência de Carl Schmitt e depois, no contexto da breve renascença do direito natural após a Segunda Guerra, como uma contribuição teológica para a formação do sistema jurídico moderno ${ }^{26}$. Apesar de suas consideráveis deficiências e reviravoltas ideológicas, essa abordagem pavimentou o caminhou para pesquisa importante sobre a história da argumentação jurídica e das instituições a partir dessa tradição católica, que foi longamente subestimada nos estudos histórico-jurídicos ${ }^{27}$.

Desde a década de 1970, a narrativa dominante sobre a Escola destacada acima foi crescentemente criticada e desafiada ${ }^{28}$. Ela está agora sendo superada por um número considerável de perspectiva diferentes, incluindo o ímpeto desconstrutivista da historiografia crítica do direito internacional, estudos profundos por historiadores da teologia e da filosofia, e em ainda dispersos estudos em história do direito. Como resultado dos últimos, está se tornando cada vez mais claro que Francisco de Vitoria era ele mesmo parte de uma ampla corrente intelectual que não havia começado em Salamanca, mas chegou lá junto com ele - o que também significa que ela chegou lá depois que em Paris, talvez também depois que em Colônia ou Lovaina. Quanto mais os autores salmantinos são investigados, mais claras as ligações de seu pensamento à tradição se tornam. Portanto, ir além da perspectiva local (Salamanca) e nacional (Espanha) e integrar Salamanca em um contexto europeu e interdisciplinar mais amplo, assim como abandonar a concentração exclusiva na história do direito internacional relativizou cada vez mais o status especial da Escola. Hesitantemente, mas com argumentos cada vez mais convincentes, a divisão "medieval-moderno" está sendo superada nesse campo, também ${ }^{29}$. A atenção está gradualmente sendo direcionada à época

\footnotetext{
${ }^{26}$ Ver, por exemplo: THIEME, Hans. Natürliches Privatrecht und Spätscholastik. Zeitschrift der SavignyStiftung für Rechtsgeschichte. Germanistische Abteilung, [s. l.], v. 70, n. 1, p. 230-266, 1953. Disponível em: $<$ https://doi.org/10.7767/zrgga.1953.70.1.230>.

${ }^{27}$ Ver, por exemplo: JANSEN, Nils. Theologie, Philosophie und Jurisprudenz in der spätscholastischen Lehre von der Restitution. Außer-vertragliche Ausgleichsansprüche im frühneuzeitlichen Naturrechtsdiskurs. Tübingen: Mohr Siebeck, 2013; DECOCK, Wim. Theologians and Contract Law: The Moral Transformation of the Ius Commune (ca. 1500-1650). Leiden: Brill Nijhoff, 2012.

${ }^{28}$ Para um exemplo de uma crítica inicial, ver: LALINDE ABADIA, Jesús. Anotaciones historicistas al iusprivatismo de la segunda escolástica. In: GROSSI, Paolo (org.). La Seconda scolastica nella formazione del diritto privato moderno. Incontro di studio, Firenze 16-19 ottobre 1972. Milano: Giuffrè, 1973. p. 303-375; LALINDE ABADIA, Jesús. Una ideología para un sistema (La simbiosis histórica entre el iusnaturalismo castellano y la Monarquía Universal). Quaderni fiorentini per la storia del pensiero giuridico moderno, [s. l.], v. 8, p. 62-156, 1979.

${ }^{29}$ Sobre essa necessidade, ver: MULDOON, James (org.). Bridging the medieval-modern divide: medieval themes in the world of the reformation. Farnham: Ashgate, 2013. Sobre a filosofia tardo medieval, ver: SCHMUTZ, Jacob. From Theology to Philosophy: The Changing Status of the Summa Theologiae, 1500-2000. In: HAUSE, Jeffrey (org.). Aquinas's Summa Theologiae: A Critical Guide. Cambridge; New York: Cambridge University Press, 2018. p. 221-241. Disponível em: <https://doi.org/10.1017/9781316271490>. Para a expansão medieval para as ilhas canárias, ver: EGÍO GARCÍA, José Luis; BIRR, Christiane. Before Vitoria: Expansion
} 
antes de Colombo e às linhas que podem ser desenhadas entre Vitoria e autores tanto anteriores quanto contemporâneos em outros locais ${ }^{30}$. O estilo apologético e às vezes até hagiográfico de escrever sobre Vitoria pode ainda ser encontrado, mas ao mesmo tempo existem mais e mais estudos de uma perspectiva pós-colonial que consideram Vitoria e outros pensadores da Escola como simplesmente outra face do império e como arquitetos do colonialismo e justificadores da exploração e do imperialismo jurídico ${ }^{31}$.

Até a posição única de Vitoria em Salamanca é crescentemente posta em questão, embora não particularmente devido ao ceticismo geral sobre a busca por "inventores" ou "pais fundadores" em estudos literários e históricos - uma perspectiva crítica surpreendentemente ausente na historiografia ou na pesquisa jurídica sobre a história da Escola de Salamanca ${ }^{32}$. Mais que isso, uma série de estudos individuais mostra quanto Vitoria dependeu de autores anteriores e estava inserido em contextos discursivos compreensíveis - notavelmente com Domingo de Soto, que no meio-tempo veio a ser visto como o autor com maior impacto nas gerações subsequentes ${ }^{33}$. Vários dos argumentos de Vitoria contra a conquista haviam sido propostos antes dele, e várias das invenções atribuídas a ele estavam firmemente enraizadas na tradição: até o que talvez seja considerado seu mais famoso argumento a respeito do que foi chamado de ius communicationis pode ser encontrado mutatis mutandis em Cícero e

into Heathen, Empty or Disputed Lands in Late-Mediaeval Salamanca Writings and Early 16th-Century Juridical Treatises. In: TELLKAMP, Jörg Alejandro (org.). A Companion to Early Modern Spanish Imperial Political and Social Thought. Leiden; Boston: Brill, 2020. p. 53-77; EGÍO GARCÍA, José Luis; BIRR, Christiane U. Alonso de Cartagena y Juan López de Palacios Rubios. Dilemas suscitados por las primeras conquistas atlánticas en dos juristas salmantinos (1436-1512). Azafea: Revista de Filosofía, [s. l.], v. 20, p. 09-36, 2018. Disponível em: <https://doi.org/10.14201/17705>.

${ }^{30}$ FERNÁNDEZ-ARMESTO, Felipe. Before Columbus: exploration and colonization from the Mediterranean to the Atlantic 1229-1492. 3. ed. Philadelphia, Pa: Univ. of Pennsylvania Press, 1994. Para uma perspectiva histórico-jurídica, ver: PÉREZ VOITURIEZ, Antonio. Problemas jurídicos internacionales de la conquista de Canarias. Las Palmas de Gran Canaria: Universidad de La Laguna, 1958; OLMEDO BERNAL, Santiago. El dominio del Atlántico en la baja Edad Media: los títulos jurídicos de la expansión peninsular hasta el Tratado de Tordesillas. Valladolid: Sociedad V Centenario del Tratado de Tordesillas, 1995.

$31 \mathrm{Um}$ texto frequentemente citado é: ANGHIE, Antony. Imperialism, sovereignty, and the making of international law. Cambridge: Cambridge University Press, 2005. Para um levantamento de abordagens póscoloniais recentes ao estudo da Escola de Salamanca, ver, por exemplo: KOSKENNIEMI, Martti. Vitoria and Us: Thoughts on Critical Histories of International Law. Rechtsgeschichte - Legal History, [s. l.], n. 22, p. 119138, 2014. Disponível em: 〈https://doi.org/10.12946/rg22/119-138>.

${ }^{32}$ Sobre esse criticismo e seu impacto na história da ciência, ver, por exemplo: SECORD, James A. Knowledge in Transit. Isis, [s. l.], v. 95, n. 4, p. 654-672, 2004. Disponível em: 〈https://doi.org/10.1086/430657〉.

${ }^{33}$ Ver: SCATTOLA, Merio. Domingo de Soto e la fondazione della scuola di Salamanca. Veritas, Porto Alegre, v. 54, n. 3, p. 52-70, 2009. Disponível em: <https://doi.org/10.15448/1984-6746.2009.3.6416 WAGNER, Andreas. Zum Verhältnis von Völkerrecht und Rechtsbegriff bei Francisco de Vitoria. In: BUNGE, Kirstin; SPINDLER, Anselm; WAGNER, Andreas (org.). Die Normativität des Rechts bei Francisco de Vitoria. Stuttgart: Frommann-Holzboog, 2011. p. 255-286; TELLKAMP, Jörg A. Vitorias Weg zu den legitimen Titeln der Eroberung Amerikas. In: BUNGE, Kirstin; SPINDLER, Anselm; WAGNER, Andreas (org.). Die Normativität des Rechts bei Francisco de Vitoria. Stuttgart: Frommann-Holzboog, 2011. p. 147-170. 
Tomás de Aquino ${ }^{34}$. Assim, Francisco de Vitoria era sem dúvidas uma figura excepcional e um professor impressionante, mas na análise final ele era também um pupilo de outros e um interlocutor de muitos ${ }^{35}$. Um grande escolástico, ele fez face às auctoritates, ordenando-as com as circunstâncias particulares do seu tempo em mente, e integrando-as em um esquema uniforme de direito natural e internacional em um período específico ${ }^{36}$. O que o fez tão especial foi que o que ele dizia era altamente carregado politicamente, e expressado em um contexto histórico da teologia marcado por conflito e disputas entre escolas ${ }^{37}$.

O que essa abordagem crítica da tradição de pesquisa significa para a noção de uma "Escola de Salamanca"? Quando a Escola era basicamente compreendida como sendo uma contribuição nacional à história dos estudos (jurídicos) europeus, com Salamanca como seu centro exclusivo, esse consenso implícito determinava a seleção das fontes relevantes (os grandes tratados) que eram examinados, o local para ser observado (a Universidade de Salamanca), assim como a perspectiva da maioria da pesquisa histórico-jurídica realizada (contribuições à história da cientifização do direito). Devido à abordagem geral dos estudos históricos do fim do século XIX e início do século XX, a história intelectual era basicamente uma história de autores (não de livros) em busca de origens e pais fundadores, não um mecanismo de produção de conhecimento. Apesar da grande importância das descobertas feitas com base nesse consenso e a partir dessas perspectivas - devida em parte àqueles acadêmicos cuja estrutura política de pesquisa nós talvez não compartilhemos hoje -, parece oportuno abrir nossa análise para incluir outras dimensões que eram inerentes a (e talvez características da) Escola, mas que ainda não foram estudadas, particularmente em função das dependências estruturais resultantes da tradição historiográfica. Dois aspectos que parecem especialmente importantes são a orientação pragmática da Escola, que foi enfatizada por

\footnotetext{
${ }^{34}$ SCATTOLA, Merio. Das Ganze und die Teile. Menschheit und Völker in der naturrechtlichen Kriegslehre von Francisco de Vitoria. In: BRIESKORN, Norbert; STIENING, Gideon (org.). Francisco de Vitorias "De Indis" in interdisziplinärer Perspektive. Stuttgart: Frommann-Holzboog, 2011; PAGDEN, Anthony. The Christian Tradition. In: BUCHANAN, Allen E.; MOORE, Margaret (org.). States, nations, and borders: the ethics of making boundaries. Cambridge; New York: Cambridge University Press, 2003. p. 103-126.

${ }^{35}$ Ver, por exemplo: SCATTOLA, Merio. Die Systematik des Natur- und Völkerrechts bei Francisco de Vitoria. In: BUNGE, Kirstin; SPINDLER, Anselm; WAGNER, Andreas (org.). Die Normativität des Rechts bei Francisco de Vitoria. Stuttgart: Frommann-Holzboog, 2011. p. 351-391.

${ }^{36}$ SCATTOLA, Merio. Das Ganze und die Teile. Menschheit und Völker in der naturrechtlichen Kriegslehre von Francisco de Vitoria. In: BRIESKORN, Norbert; STIENING, Gideon (org.). Francisco de Vitorias "De Indis" in interdisziplinärer Perspektive. Stuttgart: Frommann-Holzboog, 2011.

${ }^{37}$ Sobre esse contexto, ver: BARRIENTOS GARCÍA, José. La teología, siglos XVI-XVII. In: RODRÍGUEZSAN PEDRO BEZARES, Luis Enrique (org.). Historia de la Universidad de Salamanca. v. 3/1. 1. ed. Salamanca: Ediciones Universidad de Salamanca, 2002; QUANTIN, Jean-Louis. Catholic Moral Theology, 1550-1800. In: LEHNER, Ulrich L.; MULLER, Richard A.; ROEBER, A. G. (org.). The Oxford Handbook of Early Modern Theology, 1600-1800. Oxford; New York: Oxford University Press, 2016. p. 119-134.
} 
historiadores da teologia, mas só parcialmente considerada na historiografia jurídica ${ }^{38}$, e a sua participação em um processo de produção global de conhecimento, diferentes aspectos que são explorados nos estudos de caso neste volume.

Mas qual pode ser o aspecto de uma história da Escola de Salamanca escrita como uma história de produção - global - de conhecimento que compreende tanto teoria quanto prática? O de uma história que olha muito além de Salamanca: para o México, Guatemala, Manila, China, Coimbra, Évora? - Para compreender isso, nós temos que olhar com mais cuidado para o profundo entrelaçamento e até inseparabilidade de teoria e prática na Escola de Salamanca, algo frequentemente esquecido.

\section{CONSTRUÇÃO DE SISTEMAS E PRÁTICA DIÁRIA}

Como é bem sabido e foi examinado com grande detalhamento nas últimas décadas, os acadêmicos da Universidade de Salamanca e do monastério dominicano de San Esteban, na mesma cidade, estavam trabalhando em uma tarefa nada menor que a de refletir sobre a ordem do mundo em todas as suas dimensões. Os teólogos podiam conceber essa ordem só como a ordem divina de ser, da qual todo o resto - a ordem natural, a ordem econômica e a ordem normativa - derivava. Desde a década de 1530, o trabalho-chave para entender a realidade era - particularmente para os dominicanos, mas não apenas para eles - a Summa Theologiae de Tomás de Aquino. Já durante sua estadia em Paris, Francisco de Vitoria havia auxiliado seu professor, Petrus Crockaert, na preparação de uma edição da Summa de Tomás de Aquino. Após sua chegada em Salamanca, em 1526, ele baseou sobre isso suas conferências na classe mais importante, a Prima. De lá em diante, a Summa proveu a arquitetura do conhecimento, o escolasticismo os métodos e as práticas acadêmicas, e as auctoritates o conteúdo das aulas. Várias dessas auctoritates estavam contidas na própria Summa, nos comentários do Aquinate sobre as Sentenças de Pedro Lombardo - o último sendo um trabalho famoso que era amplamente utilizado ainda -, e em outras coleções de autoridades. No processo de preparação de suas aulas, teólogos e canonistas de Salamanca trabalhavam sobre seus sistemas teológicos e filosóficos e produziam tratados volumosos

\footnotetext{
${ }^{38}$ Especialmente Juan Belda Plans insistiu no seu caráter pragmático; ver: BELDA PLANS, Juan. Teología práctica y escuela de Salamanca del siglo XVI. Cuadernos salmantinos de filosofía, [s. l.], n. 30, p. 461-489, 2003; para uma perspectiva histórico-jurídica, ver: DECOCK, Wim. From Law to Paradise: Confessional Catholicism and Legal Scholarship. Rechtsgeschichte - Legal History, [s. l.], n. 18, p. 12-43, 2011. Disponível em: <https://doi.org/10.12946/rg18/012-034>.
} 
dentro de um gênero especializado dedicado às questões de justiça e direito que partiam da tradição dos comentários sobre a Summa, dos quais os tratados De iustitia et iure e De legibus são os mais famosos exemplos ${ }^{39}$. Esses e outros livros de Salamanca, inclusive algumas das conferências "extraordinárias", as famosas Relectiones, foram estudadas por gerações de estudantes e constituem o núcleo do que é considerado o mais importante legado da Escola.

Para teólogos, no entanto, desde a Idade Média a ordem de ser era sobretudo aquela que deveria guiar a conduta humana ${ }^{40}$. A posição proeminente de Salamanca como um local de consulta desde a época dos Reis Católicos significava que várias pessoas se dirigiam para lá, e particularmente para o monastério dominicano de San Esteban, com todos os tipos de dúvidas morais. Toda uma série de circunstâncias contribuiu para o fato de que havia uma incerteza generalizada sobre o que era moralmente duvidoso e o que não era, o que era justo ou injusto. A sobrecarga de informações no início da Modernidade havia tornado tantas opiniões disponíveis que era difícil se orientar e as Reformas dentro e forma do mundo católico, acaloradas controvérsias entre os assim chamados doctores modernos e outros, produziram afirmações contraditórias sobre dogmas teológicos, tal qual sobre como avaliar e julgar questões-chave da vida em sociedade. Ademais, a expansão europeia no Atlântico transformou a Castela de uma economia agrária atrasada em um centro do comércio mundial em poucas décadas, à medida que enormes quantidades de prata fluíram para Sevilha e uma onda de especulação, inflação e dívida se seguiu. Tanto riscos econômicos quanto morais proliferavam, e as pessoas estavam com medo de que certos atos colocariam a salvação de suas almas em risco.

Tudo isso ganhou momentum precisamente nas décadas entre a chegada de Vitoria a Salamanca em 1526 e sua morte em 1546. Questões velhas, mas agora novamente relevantes, a respeito da legitimidade de formas de comércio particulares, de empréstimos de dinheiro e de novos instrumentos bancários tinham de ser resolvidas. Várias dessas muito mundanas

\footnotetext{
${ }^{39}$ Sobre esses tratados ver: FOLGADO, Avelino. Los tratados De legibus y De iustitia et iure en los autores españoles del siglo XVI y primera mitad del XVII. La Ciudad de Dios, [s. l.], v. 72, n. 3, p. 275-302, 1959; BARRIENTOS GARCÍA, José. Los Tratados "De Legibus” y "De Iustitia et Iure" en la Escuela de Salamanca de los siglos XVI y XVII. Salamanca: revista de estudios, [s. l.], n. 47, p. 371-415, 2001.

${ }^{40}$ Sobre a emergência da ética prática no fim da Idade Média e sobre a história da teologia, ver: MANDRELLA, Isabelle. Der Dekalog als Systematisierungsschlüssel angewandter Ethik im 13. und 14. Jahr-hundert. In: KORFF, Wilhelm; VOGT, Markus (org.). Gliederungssysteme angewandter Ethik. Ein Handbuch. Nach einem Projekt von Wilhelm Korff. Freiburg; Basel; Wien: Herder, 2016. p. 228-255. Para a casuística posterior, também no período da Escola de Salamanca, ver: MÜLLER, Sigrid. Die Bedeutung des Dekalogs für die Entwicklung der neuzeitlichen Moraltheologie im Zeichen der Kasuistik. In: KORFF, Wilhelm; VOGT, Markus (org.). Gliederungssysteme angewandter Ethik. Ein Handbuch. Nach einem Projekt von Wilhelm Korff. Freiburg; Basel; Wien: Herder, 2016. p. 256-283.
} 
questões inspiravam os grandes tratados da Escola. O De iustitia et iure de Domingo de Soto, por exemplo, focava sobre os vários problemas ao redor da questão do "preço justo". Afirmava De Soto explicitamente que eram esses problemas práticos causados pelo comércio e pelos negócios que o faziam escrever seu tratado de vários volumes ${ }^{41}$, que posteriormente passou por mais de 30 edições e é visto como o trabalho central ao menos da primeira geração da Escola de Salamanca ${ }^{42}$.

Precisamente em função de suas orientações pragmáticas, os acadêmicos de Salamanca não só produziram grandes comentários sobre a Summa de Tomás de Aquino e tratados, como De iustitia et iure, ou De legibus, mas também literatura pragmática: manuais menores para aqueles engajados na prática normativa, particularmente manuais de confissão ${ }^{43}$. Esses incluíam sucessos de venda como o Manual de confessores de Martín de Azpilcueta, um livro eminentemente pragmático, escrito pelo mais respeitado canonista e teólogo moral de seu tempo, que não só passou por 90 edições, mas também foi reformulado em sumários, compêndios e epítomes ${ }^{44}$. Também as Relectiones, que circulavam em forma de manuscrito (embora algumas, mas não todas, fossem posteriormente também impressas), atraíram muita atenção. Em vários casos, elas lidavam com problemas altamente disputados de grande significância. As Relectiones de Vitoria sobre as Índias e sobre a guerra justa são o caso mais famoso, mas não o único. As Relectiones de Domingo de Soto e de Melchior Cano sobre a doutrina sacramental - a primeira publicada só postumamente, enquanto a de Cano passou por diversas edições já durante a vida do autor - lidavam com questões teológicas muito importantes e de grande e direta relevância para a vida diária.

\footnotetext{
${ }^{41}$ SOTO, Domingo de. De iustitia et iure. Salamanca: Andrés Portonaris, 1556, Liber VI, 505: "Eo denique destinati operis perventum nobis est, cuius praecipue gratia de illo coepimus cogitare. Haec inquam usurarum, contractuum, cambiorumque ac simoniarum sylva in animum potissime nobis induxit, ut tantam operem molem aggrederemur". Ver também: SOTO, Domingo de. De iustitia et iure. Salamanca: Andrés Portonaris, 1556, Prooemium, 5: “[...] peperit tamen humana libido per temporum iniquitatem, parturitque in dies novas fraudulentiae formas, quibus contra ius \& fas suam quisque expleat insatiabilem avaritiam. Quapropter nihil aliud quam operae pretium arbitrandum est si iniqua pacta \& conventa, \& cambia, tamquam adeo multa usurae simoniaeque recentia genera in animum nobis induxerunt, nova de re veteri volumina aedere".

${ }^{42}$ Ver: SCATTOLA, Merio. Domingo de Soto e la fondazione della scuola di Salamanca. Veritas, Porto Alegre, v. 54, n. 3, p. 52-70, 2009. Disponível em: 〈https://doi.org/10.15448/1984-6746.2009.3.6416>.

${ }^{43}$ Ver, sobre isso, as contribuições em: DUVE, Thomas; DANWERTH, Otto (org.). Knowledge of the Pragmatici: Legal and Moral Theological Literature and the Formation of Early Modern Ibero-America. Leiden; Boston: Brill | Nijhoff, 2020. Disponível em: <https://doi.org/10.1163/9789004425736>.

${ }^{44}$ BRAGAGNOLO, Manuela. Managing Legal Knowledge in Early Modern Times. Martín de Azpilcueta's Manual for Confessors and the Phenomenom of 'Epitomisation'. In: DUVE, Thomas; DANWERTH, Otto (org.). Knowledge of the Pragmatici: Legal and Moral Theological Literature and the Formation of Early Modern IberoAmerica. Leiden: Brill | Nijhoff, 2020. p. 187-242. Disponível em: <https://doi.org/10.1163/9789004425736>.
} 
Até as conferências regulares sobre teologia frequentemente abordavam questões sobre as práticas correntes - e frequentemente eram abertamente críticas a elas ${ }^{45}$. Vitoria, por exemplo, comentava em uma de suas conferências de teologia sobre a prática comum de cumprir o dever de restituição - um pré-requisito para receber absolvição na confissão através da aquisição de uma compositio, parte da assim chamada "indulgência das cruzadas" (Bulla de la Santa Cruzada), por uma fração do valor devido. Esse modo de restituição era oferecido em casos em que se sabia que era necessário restituir um bem adquirido ilegitimamente, mas que não era possível encontrar a pessoa para quem era devido - uma ocorrência frequente em tempos de guerra, mortes súbitas, peregrinações, especialmente no Novo Mundo, onde soldados e mercadores faziam espólios injustificados e encomenderos exploravam a população indígena e depois temiam pela salvação de suas almas. Vitoria chamava essa prática, que era de enorme significância econômica tanto para a Igreja e para a Coroa, a "maior piada do mundo". E isso não era apenas sua opinião pessoal ou um comentário aleatório que ele fazia em aula. Ao contrário, era resultado de uma análise minuciosa do potestas e dominium papal, que se baseava em argumentos similares aos que ele havia empregados em sua Relectio De Indis de 1539 a respeito do direito do Papa de atribuir os territórios recém-descobertos do Novo Mundo à Coroa espanhola. Ademais, de uma de suas cartas nós sabemos que ele também colocava em prática como um confessor o que ele ensinava em aula. Em resposta a um pedido de aconselhamento sobre a prática da compositio através da aquisição da Bulla de la Cruzada, ele escreveu: "Eu não prego contra ela [sc. a compositio] [...] mas tão pouco eu dou absolvição a alguém”. Esse é só um dos vários exemplos de como os problemas cotidianos da vida política, social e econômica, as deliberações sistemáticas baseadas na Summa, e o ofício pastoral, a cura animarum, estavam entrelaçados ${ }^{46}$.

No entanto, como não apenas mercadores e soldados, mas também o imperador, reis e cardeais consultavam os acadêmicos de Salamanca, eles também lidavam com as grandes questões políticas de seu tempo. Expansões, reformas e guerras clamavam por reflexão intensa sobre poder, obediência, hierarquia e heresia, e grandes trabalhos sobre a história do

\footnotetext{
${ }^{45}$ Sobre as práticas de ensino e acadêmicas na faculdade de teologia em Salamanca desde 1560, ver atualmente o trabalho monumental de: BARRIENTOS GARCÍA, José. La Facultad de Teología de la Universidad de Salamanca a través de los Libros de Visita de Cátedras (1560-1641). Madrid: Sindéresis, 2018.

${ }^{46}$ Ver sobre esse caso: DUVE, Thomas. ¿'La mayor burla del mundo'? Francisco de Vitoria y el dominium del Papa sobre los bienes de los pobres. In: CRUZ CRUZ, Juan (org.). Ley y domino en Francisco de Vitoria. Pamplona: EUNSA, 2008. p. 93-106.
} 
pensamento político e jurídico foram escritos sobre essas questões. Acadêmicos salmantinos participaram no Concílio de Trento e nas várias assim chamadas juntas, comitês ad hoc instituídos pelo imperador para consultas sobre problemas particulares. Eles escreveram opiniões especializadas sobre a doutrina da justificação, sobre o casamento do rei inglês Henrique VIII, sobre o Erasmianismo, sobre o legado da presença castelhana nas Américas, sobre guerra justa, sobre o batismo de membros dos povos indígenas e sobre a escravidão. Foram sobretudo as posições adotadas por Francisco de Vitoria sobre os problemas morais levantados pela invasão do Novo Mundo que o fizeram - e com ele, Salamanca - famoso. Os problemas no entorno da conquista eram também práticos, não meramente teóricos. A questão que estava movendo corações e mentes era não menos que se ela colocava em perigo a salvação daqueles envolvidos na Conquista, incluindo as almas do próprio imperador e de seus conselheiros.

Em resumo, os autores da Escola de Salamanca não escreviam só grandes tratados sistemáticos, mas também literatura pragmática, e respondiam a questões individuais concretas e específicas. Eles o faziam em razão da tradição teológica e das práticas que emergiam dela, especialmente no forum internum, que os obrigava a inquirir sobre os detalhes de cada caso para encontrar a resposta adequada, mas também porque, na Ibéria do século XVI, consultar era uma prática cultural profundamente enraizada. No nível mais alto, a cultura de consultar se manifestava nas juntas reais, na importância dos confessores reais, e em instituições como a Mesa da Consciência e Ordens, estabelecida pela Coroa portuguesa em $1532^{47}$. Em esferas menos exaltadas, padres e teólogos morais estavam lidando com uma multitude de pedidos diários por aconselhamento ${ }^{48}$. Como confessores, eles decidiam sobre pecados, maiores e menores; como consultores, eles devam sua opinião sobre assuntos da vida diária - ou, como Francisco de Vitoria enfatizava: "E não é serviço de Deus responder aos casos, senão àqueles que perguntam para sanear suas consciências e que fazem aquilo que se

\footnotetext{
${ }^{47}$ Sobre a significância dos confesores e da teologia moral para a cultura e governança política na Castela, ver, por exemplo: MARTÍNEZ PEÑAS, Leandro. El confesor del rey en el Antiguo Régimen. Madrid: Editorial Complutense, 2006; SOSA MAYOR, Igor. El noble atribulado: nobleza y teología moral en la Castilla moderna (1550-1650). Madrid: Marcial Pons, 2018. Sobre a Mesa da Consciência e Ordens na monarquia portuguesa, ver: MARCOCCI, Giuseppe. Conscience and Empire: Politics and Moral Theology in the Early Modern Portuguese World. Journal of Early Modern History, vol. 18, n. 5, p. 473-494, 2014.

${ }^{48}$ Ver: GONZÁLEZ POLVILLO, Antonio. El gobierno de los otros: confesión y control de la conciencia en la España moderna. Sevilla: Universidad de Sevilla, Secretariado de Publicaciones, 2010; O’BANION, Patrick J. The Sacrament of Penance and Religious Life in Golden Age Spain. University Park (PA): Pennsylvania State University Press, 2012.
} 
diz a eles." ${ }^{49}$. Essa priorização do aconselhamento concreto sobre cada caso individual aponta para uma característica essencial do modus operandi da Escola: cada caso tinha que ser considerado cuidadosa e individualmente, em seu contexto único, para que a decisão correta fosse encontrada, e essa decisão deveria ser feita à luz do conhecimento existente sobre os princípios da justiça.

Isso já mostra que encontrar a resposta certa para um problema não era simplesmente uma questão de saber onde buscar as normas relevantes, mas o produto de uma ars. Essa ars podia apenas ser performada adequadamente por experts - e, como uma ars, só podia ser aprendida de professores, e através da integração em uma "Escola" de prática. Um breve olhar sobre essa ars pode, então, ajudar a ilustrar porque o raciocínio da Escola só pode ser entendido adequadamente se ele for considerado não apenas como entrelaçado com a vida e a prática diária, mas enquanto prática.

\section{ARS INVENIENDI}

O que pode ser chamado de ars invendi do início da Modernidade, o modo de alcançar uma resposta adequada para uma dúvida moral, era baseado em uma prática específica de reunir ratio e auctoritas $^{50}$. A chave para entender essa operação intelectual encontra-se na

\footnotetext{
${ }^{49}$ Francisco de Vitoria, "Disensiones del reverendo padre maestro fray Francisco de Vitoria": "Y no es servicio de Dios responder a los casos, sino a los que preguntan por sanear sus conciencias y hacen lo que se les dice" (VITORIA, Francisco de. Disensiones del reverendo padre maestro fray Francisco de Vitoria sobre ciertos tratos de mercaderes. In: ZORROZA HUARTE, María Idoya (org.). Francisco de Vitoria. Contratos y usura. Pamplona: Ediciones Universidad de Navarra, 2006. p. 301-306. p. 302).

${ }^{50}$ Obviamente, o método tomista da Escola de Salamanca, assim como a relação entre ratio e auctoritas, eram problemas complexos, e as variadas posições tomadas por diferentes autores e gerações de acadêmicos não podem ser analisadas em detalhe aqui. O trabalho mais influente sobre a história da teologia moral que também discute esses problemas é: MAHONEY, John. The making of moral theology: a study of the Roman Catholic tradition. Reprinted ed. Oxford; New York: Clarendon press, 1989. Ver também, sobre o período moderno: THEINER, Johann. Die Entwicklung der Moraltheologie zur eigenständigen Disziplin. Regensburg: Friedrich Pustet, 1970; VEREECKE, Louis. Storia della teologia morale moderna. v. 2. Roma: Academia Alfonsiana, 1973; VIDAL, Marciano. Historia de la teología moral: La moral en la Edad Moderna (s. XV-XVI). T. 4 (Humanismo y Reforma). v. 1. Madrid: Perpetuo Socorro, 2012. Mais especificamente sobre Salamanca, o melhor tratamento dessas questões de uma perspectiva teológica é oferecido por: BELDA PLANS, Juan. La escuela de Salamanca y la renovación de la teología en el siglo XVI. Madrid: Biblioteca de Autores Cristianos, 2000, especialmente 207-312 (sobre o tomismo) e 619-750 (sobre a relação entre ratio e auctoritas). A questão é proximamente relacionada ao debate sobre se a casuística teológica do início da Modernidade era mais prudencial ou mais jurídica em caráter; ver, sobre isso: QUANTIN, Pierre Michaud. A propos des premières Summae confessorum: Théologie et droit canonique. Recherches de théologie ancienne et médiévale, [s. l.], v. 26, p. 264-306, 1959. Sobre a pluralidade de opiniões na um pouco posterior Barockscholastik e no probabilismo do início da Modernidade como a resposta intelectual para a pluralidade de opiniões, ver: SCHÜSSLER, Rudolf. Meinungspluralismus in Moraltheologie und Kasuistik - seine Grundlegung im Barock. In: KORFF, Wilhelm; VOGT, Markus (org.). Gliederungssysteme angewandter Ethik. Ein Handbuch. Nach
} 
premissa epistemológica fundamental de teólogos (e juristas) dos séculos XVI e XVII de que os textos aos quais se podia recorrer, as auctoritates, não continham soluções prontas para todos os casos. Em vez disso, elas eram concretizações, e, por isso, apenas parte de - mas também o caminho para - uma verdade objetiva superior que não podia ser acessada diretamente. Considerando uma questão concreta, portanto, as auctoritates que o autor havia selecionado de diferentes repositórios - topoi, loci communes - como de relevância tinham que ser incluídas no processo de raciocínio, frequentemente dentro da estrutura da questão concreta, a quaestio. Como elas formavam o ponto de partida para a argumentação de alguém, o arranjo e a compilação apropriada e cuidadosa das auctoritates eram de suma importância. É por isso que muito tempo e energia eram gastos estudando as autoridades e produzindo mídias em que autoridades relevantes eram coletadas, como trabalhos de referência e literatura pragmática.

No entanto, as soluções para casos específicos não podiam ser colhidas diretamente dessas autoridades. Elas tinham que ser encontradas através de um processo racional que se valia de diferentes auctoritates e sopesava criticamente sua aplicabilidade e apropriação para o caso sob consideração; era uma prática para chegar à escolha correta na tradição de reflexões anteriores de electione opinionum. Esse era o domínio da razão, ratio e prudentia. Autoridades de produção normativa de governos eclesiásticos ou seculares tanto do passado quanto atuais eram obviamente argumentos importantes. Elas mostravam um caminho, às vezes mesmo o único caminho, para a solução correta. Em certos casos, não havia causa para dúvida, devido ao alto grau de autoridade de certos textos: a solução estava inevitavelmente dada. Mas, na maioria dos casos, as autoridades que se encontrava podiam estar abertas para interpretações divergentes ou mesmo contradizerem umas as outras. No fim, elas eram apenas auxílios para encontrar a solução e não a solução em si. Para o processo de produção da solução certa, acadêmicos então desenvolveram certas regras operacionais: um methodus e

einem Projekt von Wilhelm Korff. Freiburg; Basel; Wien: Herder, 2016. p. 284-307. Sobre a construção do argumento jurídico no campo do ius gentium: BRETT, Annabel. Sources in the Scholastic Legacy: The (re)Construction of the Ius Gentium in the Second Scholastic. In: BESSON, Samantha; D'ASPREMONT, Jean (org.). The Oxford Handbook of the Sources of International Law. Oxford; New York: Oxford University Press, 2017. p. 64-82. Disponível em: <https://doi.org/10.1093/law/9780198745365.003.0003>. Para uma reconstrução mais detalhada da forma de produzir uma afirmação normativa no início da Modernidade, ver: DUVE, Thomas. Pragmatic Normative Literature and the Production of Normative Knowledge in the Early Modern Iberian Empires (16th-17th Centuries). In: DUVE, Thomas; DANWERTH, Otto (org.). Knowledge of the Pragmatici: Legal and Moral Theological Literature and the Formation of Early Modern Ibero-America. Leiden: Brill | Nijhoff, 2020. p. 01-39. Disponível em: <https://doi.org/10.1163/9789004425736_002>, de onde algumas partes do que segue foram retiradas. 
uma teoria das fontes e de seu valor autoritativo. A isso se pode chamar de "teoria da prática", no sentido de orientações para o exercício correto dessa ars. De acordo com essa teoria, era necessário pesquisar em diferentes locais (loci, topoi) pela opinião normativa cuja verdade parcial parecesse mais apropriada para o caso individual em mãos. O contexto filosófico desse método era da topica - legal, filosófica e teológica - do início da Modernidade e o processo resultante, a dialectica. O methodus provia técnicas específicas de interpretação.

Em conjunto com essa teoria da prática explícita e formalizada - a teoria das fontes, o método -, havia também práticas de produção de normas como tal, incluindo padrões estabelecidos de ação, convenções ou conhecimento implícito sobre o modo certo de proceder. Várias dessas práticas não eram explícitas, talvez porque elas eram parte de um consenso geral, mas silencioso, e podiam tipicamente ser adquiridas apenas por integração em uma comunidade de prática, por exemplo como um estudante que estava "aprendendo ao fazer". Elas eram, em parte não menor, os elementos que determinavam o sentimento de que certas decisões podem ser justas ou injustas para um caso concreto, uma forma de dar uma posição sistemática para o que nos debates do século XIX era frequentemente chamado simplesmente de Rechtsgefühl, uma forma de integrar as circunstâncias do caso concreto à decisão correta. Francisco de Vitoria expressou a necessidade de conhecer as circunstâncias concretas em uma de suas respostas a questões gerais sobre a permissibilidade de certas práticas comerciais:

[e]u respondo de má vontade a esses casos de cambistas, sem saber quem pergunta e para quê. Pois muitos perguntam para aproveitar-se e alargar-se se lhes dão alguma permissão. E se lhes dizem algo contra seus interesses, fazem pouco caso e se burlam da doutrina e do autor. ${ }^{51}$

A pesquisa histórica sobre a produção de conhecimento presta cada vez mais atenção a essas compreensões implícitas, às regras da prática, racionalidades regulatórias, hábitos etc. Elas também podem ser consideradas como uma parte integral do conhecimento legal - ou normativo - que, por definição, também compreende práticas ${ }^{52}$. Elas têm especial importância

\footnotetext{
${ }^{51}$ Francisco de Vitoria, "Disensiones del reverendo padre maestro fray Francisco de Vitoria": "Yo respondo de mala gana a estos casos de cambiadores, sin saber quién los pide y para qué. Porque muchos los preguntan para aprovecharse y alargarse si les dan alguna licencia. Y si algo les dicen contra su interés, dáseles poco y búrlanse de la doctrina y del autor" [VITORIA, Francisco de. Disensiones del reverendo padre maestro fray Francisco de Vitoria sobre ciertos tratos de mercaderes. In: ZORROZA HUARTE, María Idoya (org.). Francisco de Vitoria. Contratos y usura. Pamplona: Ediciones Universidad de Navarra, 2006. p. 301-306. p. 302].

${ }^{52}$ Para uma discussão mais detalhada, ver: DUVE, Thomas. Pragmatic Normative Literature and the Production of Normative Knowledge in the Early Modern Iberian Empires (16th-17th Centuries). In: DUVE, Thomas; DANWERTH, Otto (org.). Knowledge of the Pragmatici: Legal and Moral Theological Literature and the
} 
em um regime de produção de conhecimento que deixou largas margens de discricionaridade para os atores, como era o caso no raciocínio normativo nos séculos XVI e XVII tanto no direito quanto na teologia, as duas disciplinas normativas principais. Várias dessas regras de prática eram compreendidas como parte dos conceitos - e, devido à sua indeterminação, de certa forma também a caixa preta - da ratio ou prudentia. Então não era por acaso que a ratio era essencial para a interpretação de todos os textos autoritativos, inclusive a Escritura, e, portanto, formatava os debates de acadêmicos salmantinos com escritores humanistas, erasmistas e protestantes. É por isso que Francisco de Vitoria enfatizava em seus ensinamentos que a ratio era decisiva: "non tantum ex auctoritate, sed ratione, utendum esse in theologia" [é necessário utilizar não apenas autoridade, mas (também) razão em teologia] ${ }^{53}$.

A respeito da questão central deste livro - se podemos compreender a Escola como uma formação histórica exclusivamente ligada a Salamanca, ou se, em vez disso, deveríamos vê-la como um caso de produção de conhecimento global -, parece importante salientar que podem ser essas regras de prática, de forma não desprezível, as "práticas da prática", e mais concretamente, a convicção de que se devia olhar para as circunstâncias de cada caso e encontrar uma solução justa para esse caso específico, que constituíram a Escola. Como um grupo, os membros da Escola compartilhavam não apenas uma teoria da prática, mas também um consenso - frequentemente implícito - sobre como traduzir as auctoritates em uma decisão justa para um caso concreto. Partes essenciais dessa ars só podiam ser aprendidas pela integração em uma comunidade que pode ser chamada, em termos retirados da história do conhecimento, de comunidade epistêmica, que era, ao mesmo tempo, uma comunidade de prática. Nós podemos, portanto, imaginar a Escola de Salamanca como tal? E quais seriam suas características principais?

\section{A ESCOLA COMO UMA COMUNIDADE EPISTÊMICA E UMA COMUNIDADE DE PRÁTICA}

Formation of Early Modern Ibero-America. Leiden: Brill | Nijhoff, 2020. p. 01-39. Disponível em: <https://doi.org/10.1163/9789004425736_002>.

${ }^{53}$ Ver o comentário [de Francisco de Vitoria] para a I ${ }^{a}$ Pars da Summa Theologiae, Q. 1, BMP, p. 78, transcrito em: VITORIA, Francisco de. Comentario a la Ia Pars de la Summa Theologiae. In: LANGELLA, Simona. La ciencia teológica de Francisco de Vitoria y la Summa Theologiae de Santo Tomás de Aquino en el siglo XVI a la luz de textos inéditos. Salamanca: San Esteban, 2013. v.1, app., p. 262-415, citação em articulus octavus, tertio, p. 360: "Tertio admonet non tantum ex auctoritate, sed ratione, utendum esse in theologia, quia scientiae humanae sunt quoque a Deo et eas debemus adducere in obsequium Christi." 
Se nós nos voltarmos agora para os teólogos de Salamanca com essas conclusões em mente, existem alguns aspectos que poderiam ser levados em conta quando explorando a Escola de Salamanca como uma comunidade epistêmica no sentido de um grupo de pessoas com conhecimento, expertise e crenças compartilhadas, e - devido à importância das práticas - também como uma comunidade de prática ${ }^{54}$.

Alguns poderiam ser chamados de aspectos mais subjetivos, a exemplo da autopercepção de pertencimento a uma escola que começou com Vitoria. Melchior Cano, que discordou de visões de Vitoria em um bom número de casos, é um bom exemplo. Ele não só chamou Vitoria de o "maior doutor de teologia que a Espanha recebeu de Deus", ele também usou explicitamente a expressão de uma schola, mesmo que seu uso do termo possa também ter sido simplesmente em função do fato de que ele também serviu para denominar o escolasticismo em geral, sublinhando o fato de que aqueles que seguiam Tomás de Aquino se viam claramente como parte de uma comunidade diacrônica ${ }^{55}$.

No mesmo contexto, Cano também apontou para o espírito caracteristicamente crítico dentro da Escola. Em seu De locis theologicis, ele reportou que Vitoria, em suas conferências, enfatizava que não se deveria jamais aceitar mesmo as visões do Aquinate sem ter refletido sobre o problema em si mesmo ${ }^{56}$. Segundo Cano, o próprio Vitoria havia sempre respeitado esse princípio, e ele, Cano, agora seguia o exemplo de Vitoria. Ele considerava os ensinamentos e exortações de Vitoria, como ele explicitamente enfatizava ${ }^{57}$, mas ele não juraria pelas palavras de seu professor: "Theologo nihil est necesse in cuiusquam iurare leges" [jurar às leis de qualquer pessoa não é necessário para um teólogo], ele escreveu, aludindo a

\footnotetext{
${ }^{54}$ As comunidades epistêmicas são frequentemente definidas como um grupo de pessoas que compartilham conhecimento, expertise, crenças, ou uma forma de ver o mundo, como um grupo de especialistas profissionais ou uma escola de pensamento consistindo em pessoas que compartilham um paradigma disciplinar no sentido kuhniano; ver: CETINA KORR, Karin. Epistemic cultures. In: RESTIVO, Sal P. (org.). Science, Technology, and Society. Oxford: Oxford University Press, 2005. Em várias definições, a comunidade epistêmica compreende apenas conhecimento em um sentido estrito, excluindo práticas. Por essa razão, parece útil esclarecer que a Escola pode ser considerada uma comunidade epistêmica e também uma comunidade de prática. Sobre essa distinção, ver: DUVE, Thomas. Pragmatic Normative Literature and the Production of Normative Knowledge in the Early Modern Iberian Empires (16th-17th Centuries). In: DUVE, Thomas; DANWERTH, Otto (org.). Knowledge of the Pragmatici: Legal and Moral Theological Literature and the Formation of Early Modern Ibero-America. Leiden: Brill | Nijhoff, 2020. p. 01-39. Disponível em: <https://doi.org/10.1163/9789004425736_002>.

${ }^{55}$ CANO, Melchor. De locis Theologicis, Libri Duodecim. Salamanca: Mathias Gast, 1563, Prooemium, fol. 385: "Fratrem Franciscum Victoria Lector optime, eum quem summum Theologiae praeceptorem Hispania dei singulari munere accepit, solitum [...] dicere audivi postqua[m] ab illi[us] schola discessi [...]."

56 CANO, Melchor. De locis Theologicis, Libri Duodecim. Salamanca: Mathias Gast, 1563, Prooemium, fol. 385: "Sed admonebat rursum, non opor-tere sancti doctoris verba sine delectu \& examine accipere [...]."

${ }^{57}$ CANO, Melchor. De locis Theologicis, Libri Duodecim. Salamanca: Mathias Gast, 1563, Prooemium, fol. 385: "[...] quod virum hunc rerum earum omnium ducem optimum sequimur, atque eius praeceptis monitisque paremus."
} 
uma famosa frase de Horácio ${ }^{58}$. Vitoria havia escrito algo muito similar em seu prefácio à edição da Summa de Tomás de Aquino de seu professor, Petrus Crockaert ${ }^{59}$. São as muitas referências mútuas como essa, a delicada textura entrelaçando o Aquinate e Vitoria com a opinião própria de alguém - e talvez a ênfase na ratio contra as auctoritates, mesmo se retiradas de sua própria Escola - que constituíam o sentido de comunidade. Essa comunidade não terminou nos pilares de Hércules: como Egío aponta em sua contribuição a este volume, escrevendo na Nova Espanha, Alonso de la Veracruz considera Vitoria como "princeps magister... olim praeceptor meus" [principal mestre [...] uma vez meu professor] ${ }^{60}$.

Outro importante aspecto que também contribuiu para a autoidentificação de pertencer a uma "escola" era a posição privilegiada que os teólogos clamavam para si próprios, especialmente em relação a juristas e canonistas ${ }^{61}$. Devido à necessidade de deliberar sobre tudo que aconteceu sub specie aeternitatis e à sua obrigação de cuidar da salvação de almas, a cura animarum, os teólogos se sentiam autorizados a dar suas opiniões em basicamente tudo. Como Vitoria reconhecidamente colocou, “[A] tarefa e ofício dos teólogos são tão abrangentes que nenhum argumento, nenhuma consideração e nenhum tópico parece estar além da competência da profissão e do ofício teológico." ${ }^{62}$ Afirmações similares podem ser encontradas no De iustitia et iure de Domingo de $\mathrm{Soto}^{63}$ e no início do século XVII no De legibus de Francisco Suárez: "Ninguém deveria ficar surpreso se alguém que se dedica à

\footnotetext{
${ }^{58}$ CANO, Melchor. De locis Theologicis, Libri Duodecim. Salamanca: Mathias Gast, 1563, Prooemium, fol. 385.

${ }^{59}$ Ver o prefácio de Francisco de Vitoria na edição de II $^{\mathrm{a}}$-II ${ }^{\mathrm{ae}}$, de Tomás de Aquino, impressa por Claudio Chevalon, Paris, 1512. O texto do prefácio nessa rara edição é transcrito em: VITORIA, Francisco de. Prefacio [Preface to the edition of Aquinas' II-IIae, Paris, 1512: Claudio Chevalon.]. In: LANGELLA, Simona. La ciencia teológica de Francisco de Vitoria y la Summa Theologiae de Santo Tomás de Aquino en el siglo XVI a la luz de textos inéditos. Salamanca: San Esteban, 2013. App. i., p. 102-109. p. 104: "in unius auctore verba iurare".

${ }^{60}$ Ver Egío neste volume [vide nota de tradução (a) acima].

${ }^{61}$ Sobre Salamanca como uma escola de juristas, com ênfase particular sobre a dimensão prática, ver: ALONSO ROMERO, María Paz. Salamanca, escuela de juristas: estudios sobre la enseñanza del derecho en el Antiguo Régimen. Madrid: Dykinson, 2012.

${ }^{62}$ Francisco de Vitoria, "De potestate civili": "OFFICIVM, ac munus Theologi tam latè patet, ut nullum argumentum, nulla disputatio, nullus locus alienus uideatur à theologica professione, \& instituto." [VITORIA, Francisco de. De potestate civili. In: VITORIA, Francisco de. Relectiones Theologicae XII. v. 1. Lugduni: Boyerius, 1557. (The School of Salamanca. A Digital Collection of Sources). Disponível em: $<$ https://id.salamanca.school/texts/W0013:vol1.5?format=html>.]

${ }^{63}$ SOTO, Domingo de. De iustitia et iure. Salamanca: Andrea de Portonaris, 1556, fol. 5: "Neque vero est quod Theologis vitio detur, hanc sibi assumere provinciam quae Iurisperitis accommodatior videri potest: quandoquidem Canonica iura ex visceribus Theologiae prodiere: Civilia vero ex media morum Philosophia. Theologi ergo est iuris Canonici decreta ad nor-mam Euangelicam exigere; philosophique Ciulia ex principiis philosophiae examinare."
} 
teologia concluir que as leis são uma matéria digna de exame crítico." ${ }^{64}$ É assim também que Francisco de Vitoria justificou a competência dos teólogos para dar suas opiniões sobre os direitos de povos indígenas nas Américas, embora, naquele caso específico, também houvesse uma razão adicional: esses povos, ele argumentava, não eram sujeitos ao ius humanum, mas tinham de ser tratados de acordo com as leges divinas. Juristas, portanto, simplesmente não eram qualificados para tomar decisões envolvendo essas leis divinas, particularmente quando o forum conscientiae estava envolvido. Apenas padres eram capazes de decidir sobre esses problemas $^{65}$.

Assim, os teólogos de Salamanca em geral viam o direito secular e canônico como ciências auxiliares, e não apenas quando decidindo sobre a solução correta para questões como o tratamento de indígenas americanos. Naturalmente era necessário conhecer ambos, pelo menos em função das implicações práticas ${ }^{66}$, como tanto juristas quanto canonistas enfatizavam $^{67}$. Obviamente, a tradição do ius commune provia auctoritates importantes que tinham de ser levadas em conta. No entanto, como concluiu o estudante e sucessor de Vitoria, Melchior Cano, no fim, as auctoritates dos juristas eram irrelevantes para teólogos em questões de fé, e de pouca ou nenhuma relevância com respeito às normas que podiam ser derivadas da lex evangelica ou da ratio. A única área onde elas poderiam ser úteis era no caso de dúvida sobre moribus ecclesiae \& religionis, isto é, sobre o que eram em último caso

\footnotetext{
${ }^{64}$ SUÁREZ, Francisco. Tractatus de legibus ac deo legislatore in decem libros distributis. Conimbricæ: Diego Gómez de Loureiro, 1612, Prooemium, fol. 1.: "Nulli mirum videri debet, si homini Theologiam profitenti leges incidant disputandae [...]."

${ }^{65}$ Francisco de Vitoria, "De Indis prior": "Secundò dico, quòd haec determinatio non spectat ad iurisconsultos, uel saltem non ad solos illos. Quia cùm illi barbari, ut statim dicam, non essent subiecti iure humano, res illorum non sunt examinandae per leges humanas, sed diuinas, quarum iuristae non satis periti ut per se possint huiusmodi quaestiones diffinire. Nec satis scio, an unquam ad disputationem \& determinationem huius quaestionis uocati fuerint Theologi digni, qui audiri de tanta re possent. Et cum agatur de foro conscientiae, hoc spectat ad sacerdotes, id est ad ecclesiam, diffinire. unde Deutero. 17. praecipitur Regi, ut accipiat exemplar legis de manu sacerdotis" [VITORIA, Francisco de. De Indis prior. In: VITORIA, Francisco de. Relectiones Theologicae XII. v. 1. Lugduni: Boyerius, 1557. (The School of Salamanca. A Digital Collection of Sources). Disponível em: 〈https://id.salamanca.school/texts/W0013:vol1.5?format=html>.]

${ }^{66}$ Ver a citação anterior de Vitoria ("vel saltem non ad solos illos") e Melchor Cano (CANO, Melchor. De locis Theologicis, Libri Duodecim. Salamanca: Mathias Gast, 1563, Liber octavus, Cap. Sextum, fol. 282: "Principio enim si a Theologis animarum cura non est aliena, sed potius animas regere eorum quasi peculiare munus est, procul dubio canonici iuris scientia est illis necessaria").

${ }^{67}$ AZPILCUETA, Martín de. Commentarii in tres de poenitentia distinctiones posteriores, videlicet V, VI et VII. Lugduni: Petrus Fradinus, 1569, Dist. 6., Cap. I, § caveat, n. 11, 188: "De iustitia enim Theologi generatim discere sciunt, quid illa est, \& quotuplex, an sit virtus cardinalis, an omnium moralium potissima, in qua potentia locanda, \& alia id genus, quae parum aut nihil confessario conferunt. Quod item iniustitia sit peccatum mortale, facile definire norunt. At definire, quando in iudiciis, in contractibus, in ultimis voluntatibus, et nonnunquam in delictis com-mittatur iniustitia in casibus innumeris, qui praeter legem naturae occurrunt, vires Theologi excedit: nisi legum quoque se peritum fecerit."
} 
regras meramente funcionais ${ }^{68}$. Então disso se pode concluir que, de acordo com a autopercepção dos atores, era necessário ser teólogo para ser parte da Escola.

À parte da autopercepção dos atores, existem boas razões para considerar a Escola de Salamanca como uma comunidade discursiva no sentido de um grupo social que difere dos outros sobretudo em suas formas específicas de discurso ${ }^{69}$, como sugerido há alguns anos por Merio Scattola ${ }^{70}$. Ele entendia o termo como denotando uma comunidade de comunicação acadêmica cujos membros apresentavam o conhecimento disponível de acordo com as normas do mesmo gênero literário, usando o mesmo estilo de escrita erudito e se referindo às mesmas autoridades. De fato, essa breve reconstrução de algumas das características da Escola mostra, assim como as contribuições para este volume, algumas dessas disposições compartilhadas, como a orientação pela Summa de Tomás de Aquino, um certo estilo de lidar com as auctoritates etc. Para a constelação característica das autoridades e estilos usados em tal comunidade discursiva, Scattola usou a ideia de uma "impressão digital", que nós podemos "obter" por uma leitura atenta dos textos - e, se pode adicionar hoje, ao fazer uso das ferramentas das humanidades digitais ${ }^{71}$.

Em vista disso, nós podemos provisoriamente conceitualizar a Escola de Salamanca como uma comunidade epistêmica e uma comunidade de prática que era caracterizada por elementos tanto subjetivos quanto objetivos. Quanto ao elemento subjetivo, nós podemos encontrar um sentido de pertencimento a uma comunidade diacrônica de professores e pupilos que reconhecem um pai fundador e que compartilham certas convicções sobre a identidade da comunidade. Parte desses elementos de construção de identidade era reivindicar um espírito crítico que privilegiava ratio sobre auctoritates, e a convicção de que era preciso expertise teológica para decidir sobre as importantes questões da justiça. Alguns dos membros dessa

\footnotetext{
${ }^{68}$ CANO, Melchor. De locis Theologicis, Libri Duodecim. Salamanca: Mathias Gast, 1563, Liber octavus, Caput Septimum, fol. 284: "Prima conclusio: In his, quae ad fidem pertinent, iurisconsultorum auctoritate theologus non eget [...]"; fol. 285: "Secunda conclusio: In his etiam, quae ad mores pertinent, quatenus vel lex evangelica, vel ratio Philosophiae de huiusmodi praescribit, iureconsultorum auctoritas parum aut certe nihil theologo conferre potest"; fol. 285-6: "Tertia conclusio: In tertio illo genere rerum, ubi scilicet de moribus ecclesiae \& religionis institutis per leges [...] iurisperitorum omnium communis consensus concorsque sententia, theologo magnam fidem facere debet."

${ }^{69}$ POGNER, Karl-Heinz. Textproduktion in Diskursgemeinschaften. In: JAKOBS, Eva-Maria; KNORR, Dagmar; POGNER, Karl-Heinz (org.). Textproduktion: HyperText, Text, KonText. Frankfurt am Main: P. Lang, 1999, p. 146: "Diskursgemeinschaften zeichnen sich durch unterschiedliche, spezifische Muster des Sprachgebrauchs (und des Denkens) bei der sozialen Konstruktion und Aushandlung von Bedeutung aus."

${ }^{70}$ SCATTOLA, Merio. Krieg des Wissens, Wissen des Krieges: Konflikt, Erfahrung und System der literarischen Gattungen am Beginn der Frühen Neuzeit. Padova: Unipress, 2006.

${ }^{71}$ Essa é uma das ideias por trás da publicação de edições digitais de trabalhos-chave da Escola de Salamanca; ver: <https://www.salamanca.school/en/project.html>.
} 
comunidade podem mesmo ter sido convencidos de que era necessário ser parte da Ordem Dominicana ou do Monastério de San Esteban, ou ao menos ensinar teologia na Universidade de Salamanca para ser um membro da comunidade; alguns dos fatores subjetivos que constituem uma escola podem divergir, até um certo grau. Outros podem ter reclamado que um consenso básico sobre certos tópicos era essencial, ou que uma certa interpretação do Tomismo era necessária se alguém queria pertencer à comunidade, novamente com pequenas variações. Esses elementos subjetivos são relevantes, pois a autopercepção dos membros de um grupo contribui para definir sua identidade - independentemente de se essa autopercepção corresponde ao que outros pensam ou ao que uma análise posterior mostra. É possível, por exemplo, que membros de uma escola estejam absolutamente convencidos da singularidade de seu grupo, da originalidade do pensamento de seu pai fundador, ou de sua centralidade no processo de produção de conhecimento, sem que essas convicções sejam necessariamente corretas. Além do mais, a autopercepção molda práticas e assim, em alguns casos, converte elementos subjetivos em objetivos. Por exemplo, os atores podem estar convencidos de que eles estão seguindo uma certa tradição intelectual e podem realmente desenvolver convenções e práticas que correspondem a essa tradição. Por essas razões, foi sugerido que nós deveríamos falar de um certo habitus que caracterizava os membros da Escola de Salamanca $^{72}$.

Quanto aos elementos objetivos, a Escola pode ser vista como uma comunidade discursiva reconhecível por uma certa constelação do uso de autoridades, estilos de argumentação, certas regras de práticas compreendendo o que foi chamado de uma "teoria da prática", assim como de "práticas de prática". Em adição a isso, parece importante destacar a dimensão pragmática da Escola como um local de contínua consulta e produção de afirmações normativas, seja no confessional, no aconselhamento pessoal, em opiniões escritas ou no tratamento de questões práticas da vida diária ou política. Mesmo se essa atividade possa ter sido mais pronunciada em Salamanca que em outros locais, ela não era contingente, mas respondia a uma cultura histórica de consulta e era intrinsicamente ligada ao dever primário do teólogo, a cura animarum.

No debate acadêmico sobre como definir a Escola, também foi sugerido que a centralidade de certas questões - como a legitimação da Conquista, ou a necessidade de refletir sobre os desafios que emergiram como resultados da expansão do Império - podiam

\footnotetext{
72 CARABIAS TORRES, Ana María. La Escuela de Salamanca. Perspectivas de investigación. Salamanca Working Papers Series, Frankfurt am Main, n. 2015-3, 2015, p., 20.
} 
ser vistas como características da Escola ${ }^{73}$. Outros defendem uma perspectiva institucional e veem a Escola como restrita àqueles que ensinavam em Salamanca, estabelecendo um contraste acentuado entre eles e todos os outros, que eles veem como pupilos ou como pertencendo a zonas de influência. Essas tentativas de definir a Escola por um critério puramente institucional ou baseadas na posição tomada sobre um problema específico podem ser úteis para uma história da Universidade de Salamanca ou da teologia. Elas tendem, no entanto, a isolar Salamanca de seu contexto, e subestimam o caráter social da produção de conhecimento, particularmente a interação com territórios do além-mar ${ }^{74}$. Isso não acontece em esplêndido isolamento, mas, como as últimas décadas do debate crítico metodológico nas humanidades mostraram, como um processo comunicativo ${ }^{75}$. Ademais, se nós tomarmos a normatividade como sendo um sistema comunicativo consistindo em atores, condições materiais e estilos discursivos estabelecidos, é menos o conteúdo e sim o modo de produção que estrutura o sistema.

\section{UMA PERSPECTIVA DA HISTÓRIA DO CONHECIMENTO SOBRE A ESCOLA DE SALAMANCA}

Ao adotar uma abordagem tomada da história do conhecimento e conceitualizando a Escola como uma comunidade epistêmica e uma comunidade de prática - e assim como uma

\footnotetext{
${ }^{73}$ PEREÑA, Luciano. La Escuela de Salamanca: proceso a la conquista de América. Salamanca: Caja de Ahorros y Monte de Piedad de Salamanca, 1986; PEREÑA, Luciano. La Escuela de Salamanca, notas de identidad. In: GÓMEZ CAMACHO, Francisco; ROBLEDO, Ricardo (org.). El pensamiento económico en la Escuela de Salamanca: una visión multidisciplinar. Seminarios celebrados en Salamanca en 1992, 1993, y 1995 organizados por la Fundación Duques de Soria y dirigidos por el Profesor Ernest Lluch. Salamanca: Ediciones Universidad Salamanca, 1998. p. 43-64; PEREÑA, Luciano. La Escuela de Salamanca y la duda indiana. In: RAMOS, Demetrio et al. (org.). La ética de la conquista de América. Madrid: Consejo Superior de Investigaciones Científicas, 1984. p. 291-344. Sobre o debate e para outras perspectivas e referências seguintes, ver: BERMEJO, Ignacio Jericó. ¿Escuela de Salamanca y Pensamiento hispánico?: Ante una propuesta. Salmanticensis, [s. l.], v. 59, n. 1, p. 83-114, 2012; BELDA PLANS, Juan. Hacia una noción crítica de la "Escuela de Salamanca". Scripta theologica, [s. l.], v. 31, n. 2, p. 367-411, 1999; ZORROZA HUARTE, María Idoya. Hacia una delimitación de la Escuela de Salamanca. Revista Empresa y Humanismo, [s. l.], v. XVI, n. 1, p. 53-72, 2013; MARTÍN GÓMEZ, María. Francisco de Vitoria y la Escuela Ibérica de la Paz. Revista Portuguesa de Filosofia, [s. l.], v. 75, n. 2, p. 861-890, 2019. Disponível em: <https://doi.org/10.17990/RPF/2019_75_2_0861>.

${ }^{74}$ Isso é enfatizado inclusive por BRUFAU PRATS, Jaime. La Escuela de Salamanca ante el descubrimiento del Nuevo Mundo. Salamanca: Editorial San Esteban, 1989, p. 123-124: "La Escuela salmantina no puede reducirse ni al ámbito del Estudio General de la ciudad del Tormes, ni a los coetáneos e inmediatos sucesores de Vitoria. Se extiende a las nuevas universidades que surgen en tierras americanas, como México y Lima, y a generaciones de profesores formados por los que lo fueron por Vitoria y las figuras egregias de la primera hora, como Domingo de Soto, y por los discípulos de los discípulos".

${ }^{75}$ Ver, sobre isso, por exemplo: SECORD, James A. Knowledge in Transit. Isis, [s. l.], v. 95, n. 4, p. 654-672, 2004. Disponível em: 〈https://doi.org/10.1086/430657>. p. 662.
} 
participante em um sistema comunicativo - nós somos capazes de superar a definição da Escola de acordo com sua localização em um local, a afiliação institucional de seus membros, ou uma posição particular que seus membros sustentavam sobre questões importantes. Isso tem várias vantagens.

Primeiro, nos permite definir a comunidade de acordo com critérios compartilhados pelos participantes no sistema, independentemente de sua localização geográfica em Europa, Ásia, África ou América, e mesmo transcendendo fronteiras políticas e imperiais. Além disso, como as comunidades de práticas não são necessariamente estabelecidas através de comunicação direta entre seus membros, mas podem ser constituídas por um conjunto comum de autoridades, métodos ou estilos de pensamento, conceitualizar a Escola como uma comunidade epistêmica e uma comunidade de prática nos permite colocar autores e textos em relações significativas uns com os outros, independentemente de terem estado em contato direto. Vários capítulos neste volume mostram quão próximos o método e a argumentação empregados em diferentes locais eram àqueles usados em Salamanca. Isso era devido frequentemente ao contato direto ou filiação. Uma vez que os ex-estudantes estavam atuando como missionários, padres ou bispos - como Domingo de Salazar, o primeiro bispo de Manila, a quem um número de estudos neste volume se dedica (Camacho, Cobo, Moutin) -, eles continuavam a praticar o que eles haviam aprendido, frequentemente em contato com sua alma mater, formando uma comunidade que atravessava oceanos. Contato direto, no entanto, não era necessário, desde que houvesse mídias que permitissem comunicação.

Ademais, muitas vezes é impossível determinar quais textos ou práticas normativas particulares deveriam ser vistos como relacionados aos territórios europeus ou americanos dos Impérios Ibéricos, respectivamente, ou se eles se originavam de Salamanca, ou, por exemplo, do México. Um dos exemplos mais conhecidos dessas dificuldades de localizar geograficamente pessoas, ideias e textos é Alonso de la Veracruz, cujos aspectos da vida e trabalho são explorados por Egío, Folch e Aspe Armella neste volume. Veracruz estudou em Salamanca antes de se mudar para a Cidade do México para ensinar na Universidade de lá. Alguns de seus livros foram impressos no México: sua Dialectica resolutio cum textu Aristotelis, em 1554, e, dois anos depois, seu Speculum coniugiorum. O último, um tratado sobre o direito matrimonial, lidava particularmente com as questões do casamento entre as populações indígenas, como José Luis Egío mostra em sua contribuição. A segunda edição do Speculum, no entanto, foi impressa em Salamanca em 1562, o mesmo ano em que Veracruz viajou para a Espanha para passar alguns anos antes de retornar para o México, cada vez 
acompanhado por sua enorme biblioteca. Existem várias boas razões para contar um trabalho como o Speculum como parte da "Escola de Salamanca", mesmo se ele foi escrito à distância de milhares de quilômetros, e não apenas porque sua segunda edição foi impressa em Salamanca (outras vieram em Alcalá de Henares em 1572 e em Milão em 1599, as duas com Apendices a respeito das implicações das mudanças ao direito matrimonial realizadas pelo Concílio de Trento). O mesmo pode ser dito para as deliberações de Veracruz sobre a legitimidade da Conquista escritas no México, que claramente seguiram uma estrutura argumentativa que seu autor havia aprendido de Vitoria, como Aspe Armella mostra.

Outro exemplo pode ser visto no manual sobre direito contratual de Tomás de Mercado, um frei Dominicano que viveu primeiro na Nova Espanha e depois estudou em Salamanca, onde ele também publicou seu livro. O manual foi escrito a pedido dos mercadores de Sevilha, mas baseado em suas experiências no México. Um caso subsequente é o de Diego de Avendaño, que nasceu na Espanha e seguiu para ocupar numerosos cargos em Lima, onde ele escreveu seu Thesaurus indicus. Seu trabalho foi desenvolvido sobre conhecimento normativo que era produzido especialmente em Salamanca, mas ele o traduziu para realidades locais e o aplicou para sua área de interesse. Suas conclusões, portanto, diferiam daquelas de Luis de Molina, mas seu trabalho - a despeito de resultados diferentes, que podem muito bem ter sido decorrentes de ele ser um americano - claramente mostra seu pertencimento à mesma comunidade epistêmica que os escritores de Salamanca.

Em síntese, parece impossível, e na verdade contraprodutivo, identificar autores como Alonso de la Veracruz com apenas um continente ou local, ou classificá-los, em um modo colonial reverso, como pais da filosofia colonial latino-americana. Eles se moviam dentro de um espaço imperial, assim como dentro de um espaço intelectual para cujo desenvolvimento eles próprios contribuíram e que, em verdade, seguidamente se estendia para além das fronteiras do império. A biografia de Juan Cobo mostra isso muito claramente: Cobo, um dominicano que havia estudado em Ávila, viajou via México para as Filipinas, à época percebida como o portão para a China. Como a Suma de Tratos y Contratos de Tomás de Mercado, o De locis theologicis de Melchior Cano e vários outros importantes trabalhos, os de Cobo (o Shilu, por exemplo) foram impressos por Matthias Gast em Salamanca. Faz sentido separar esses autores da Escola, simplesmente em função de sua afiliação institucional ser diferente?

Se nós sairmos de casos individuais de autores e professores para outras modalidades de produção de conhecimento normativo, a necessidade de abrir nossa conceituação espacial 
da Escola e também ampliar nosso entendimento para além de um mero fenômeno acadêmico, como uma comunidade de prática, se torna ainda mais marcante. Se examinarmos o Terceiro Concílio Provincial Mexicano de 1585, de importância primordial para a história jurídica e eclesiástica da Nova Espanha ${ }^{76}$, vemos que sete dos nove bispos dessa vasta província da igreja haviam estudado ou ensinado em Salamanca, assim como o conselheiro teológico do Concílio, seu secretário - ambos que desempenharam papéis cruciais em suas deliberações - e o arcebispo convocador - que ao tempo do Concílio também atuava como Vice-rei interino haviam sido instruídos em Salamanca. Mais que isso, descobrimos que as respostas que o Concílio deu às requisições de consulta a ele direcionadas mostram similaridades importantes com aquelas que poderiam ter sido dadas em Salamanca, como aquelas concernentes à legitimidade da guerra contra os assim chamados Índios Chichimeca, por exemplo ${ }^{77}$. O Concílio também discutiu os assim chamados repartimientos (um sistema de trabalho forçado a que parte da população indígena foi submetida), práticas negociais que desfavoreciam a população indígena, e outras práticas negociais e creditícias que possivelmente envolviam usura (usura). Durante esses processos de formular decisões sobre questões centrais da vida cotidiana na Nova Espanha, o Concílio repetidamente consultou trabalhos da Escola de Salamanca; entre os autores mais citados estavam Domingo de Soto, Martín de Azpilcueta e Juan de Medina. Na medida em que podemos reconstruir o argumento avançado nas deliberações do Concílio, eles parecem ter seguido um método de produção de conhecimento que correspondia àquele usado em Salamanca, justamente como Alonso de la Veracruz havia feito antes. Certamente é importante que nós integremos esse modo de produção de conhecimento normativo em nossa concepção da Escola, inclusive porque foi essa dimensão pragmática que contribuiu para a presença, localização e tradução cultural massiva da linguagem político-jurídica da Escola muito além de Salamanca. Se considerarmos a normatividade como um sistema comunicativo compreendendo diferentes atores e se deixarmos de lado a caracterização da Escola como um empreendimento puramente acadêmico (que era o resultado de dependências estruturais provenientes do início de sua

\footnotetext{
${ }^{76}$ MOUTIN, Osvaldo Rodolfo. Legislar en la América hispánica en la temprana edad moderna: procesos y características de la producción de los Decretos del Tercer Concilio Provincial Mexicano (1585). Frankfurt am Main: Max Planck Institute for European Legal History, 2016. (Global perspectives on legal history, v. 4).

${ }^{77}$ Para uma discussão mais detalhada sobre isso, ver: DUVE, Thomas. Salamanca in Amerika. Zeitschrift der Savigny-Stiftung für Rechtsgeschichte: Germanistische Abteilung, [s. l.], v. 132, n. 1, p. 116-151, 2015. Disponível em: <https://doi.org/10.7767/zrgga-2015-0108>.
} 
historiografia no século XIX), nós não podemos ignorar esse modo de produção de conhecimento normativo.

Abrindo nossa compreensão da Escola dessa forma, nós podemos ver também que existiam vários nódulos na rede de produção de conhecimento e que informação fluía por essa rede em todas as direções, não apenas de Salamanca para as "periferias" ou entre universidades. Padres e missionários, teólogos e canonistas, e até juristas, oficiais imperiais e mercadores eram parte de uma comunidade epistêmica e uma comunidade de prática que não era restrita a certas cidades, regiões e instituições. Livros, cartas, relatórios, mas também pessoas, circulavam por vastas distâncias ${ }^{78}$. Todos eles contribuíram para traduzir a linguagem jurídico-política produzida em Salamanca - e, como nós vimos, também em alhures - em contextos locais similares, ou às vezes radicalmente diferentes. Alguns dos problemas com que eles lidavam já haviam ocupado teólogos e juristas na Europa e outros surgiam das circunstâncias locais, mas quer seja familiar ou inédito, cada caso individual tinha que ser decidido de acordo com seu contexto único e recorrendo às mesmas autoridades, à mesma teoria sobre a prática, e talvez até adotando as mesmas práticas. Com tão inumeráveis decisões e julgamentos individuais, incontáveis agentes de todos os cantos do Império contribuíram para o desenvolvimento de um conhecimento normativo fundado teologicamente. Certamente, esses processos podiam modificar o significado dos termos, e a linguagem rapidamente cresceu para além do vocabulário originalmente desenvolvido em Salamanca. No entanto, Salamanca não existia em isolamento: era um centro de conhecimento que absorveu continuamente conhecimento vindo de outras áreas e o integrou em suas discussões e deliberações, assim contribuindo para a transformação do conhecimento. Salamanca nunca foi "pura".

Conceituar a Escola como uma comunidade epistêmica e uma comunidade de prática que não era necessariamente limitada ao espaço físico de Salamanca também nos permite criar uma estrutura comparativa para colocar os autores de Salamanca no contexto tanto de escritores precedentes quanto posteriores, mesmo aqueles do mundo protestante. Como acadêmicos de todas as confissões cristãs inicialmente construíram sobre uma tradição comum, não deveria ser surpreendente descobrir que discussões na Wittenberg reformada e

\footnotetext{
${ }^{78}$ Sobre a presença da literatura pragmática de teologia moral em diferentes partes da América colonial, ver agora as contribuições em DUVE, Thomas; DANWERTH, Otto (org.). Knowledge of the Pragmatici: Legal and Moral Theological Literature and the Formation of Early Modern Ibero-America. Leiden; Boston: Brill | Nijhoff, 2020. Disponível em: 〈https://doi.org/10.1163/9789004425736〉.
} 
aquelas em Salamanca sobre o direito de governantes protestantes de resistir ao Imperador Carlos V usavam formas argumentativas similares e partiam das mesmas auctoritates embora com resultados muito diferentes ${ }^{79}$. De maneira análoga, foi mostrado que o Loci communes de Philipp Melanchthon compartilhava várias características com a teoria do direito natural da Escola de Salamanca ${ }^{80}$. E, como Scatolla argumentou, Johannes Althusius construiu de muitas maneiras sobre o que Philipp Melanchthon, e Tomás de Aquino antes dele, havia estabelecido em sua teoria do direito natural ${ }^{81}$. Em seu argumento para o direito das Províncias Unidas dos Países Baixos de resistir a Filipe II, Johannes Althusius - como Hugo Grotius e outros acadêmicos reformados - virou as armas dos próprios espanhóis contra eles mesmos ${ }^{82}$. Ditlev Tamm sugeriu que certos aspectos do trabalho do teólogo dinamarquês Niels Hemmingsen, do século XVI, poderiam proveitosamente ser interpretados com a Escola de Salamanca em mente ${ }^{83}$. Pesquisas recentes lançaram uma nova luz sobre a casuística luterana e sobre a teologia e o direito contratual luteranos e assim nos convidam a comparar técnicas de produzir conhecimento normativo para além da esfera confessional ${ }^{84}$. O mesmo pode ser verdade para os trabalhos de acadêmicos anteriores como Stanislaw de Skarbimierz (1360-1431) e Paweł Włodkowicz, Paulus Vladimiri (1370-1436), que trabalharam na Universidade de Cracóvia ${ }^{85}$. O tratado do último contra a haeresis Prussiana em particular foi frequentemente ligado ao pensamento da Escola de Salamanca, mais recentemente por Alfred Dufour $^{86}$.

\footnotetext{
${ }^{79}$ Ver também: SCATTOLA, Merio. Widerstand und Naturrecht im Umkreis von Philipp Melanchthon. In: SCHORN-SCHÜTTE, Luise (org.). Das Interim 1548/50: Herrschaftskrise und Glaubenskonflikt. Gütersloh: Gütersloher Verlagshaus, 2005. p. 459-487.

${ }^{80}$ SCATTOLA, Merio. 'Notitia naturalis de Deo et de morum gubernatione'. Die Naturrechtslehre Philipp Melanchthons und ihre Wirkung im 16. Jahrhundert. In: BAUER, Barbara (org.). Melanchthon und die Marburger Professoren. Marburg: Universitätsbibliothek Marburg, 1999. p. 865-882.

${ }^{81}$ SCATTOLA, Merio. Johannes Althusius und das Naturrecht des 16. Jahrhunderts. In: CARNEY, Frederick S.; SCHILLING, Heinz; WYDUCKEL, Dieter (org.). Jurisprudenz, Politische Theorie und Politische Theologie. Beiträge des Herborner Symposions zum 400. Jahrestag der Politica des Johannes Althusius (1603-2003). Berlin: Duncker \& Humblot, 2004. p. 371-396.

82 REIBSTEIN, Ernst. Johannes Althusius als Fortsetzer der Schule von Salamanca. Untersuchungen zur Ideengeschichte des Rechtsstaates und zur altprotestantischen Naturrechtslehre. Karlsruhe: C. F. Müller, 1955.

${ }^{83}$ TAMM, Ditlev. Rechtswissenschaft im Dienste der Theologie. Zur Stellung der Rechtswissenschaft an den nordischen Universitäten im 17. Jahrhundert. In: DÜBECK, Inger et al. (org.). Med lov skal land bygges og andre retshistoriske afhandlinger. København: Djøf, 1989. p. 185-195.

${ }^{84}$ MAYES, Benjamin T. G. Counsel and conscience: Lutheran casuistry and moral reasoning after the Reformation. Göttingen: Vandenhoeck \& Ruprecht, 2011; ASTORRI, Paolo. Lutheran theology and contract law in early modern Germany (ca. 1520-1720). Paderborn: Brill Schöningh, 2019.

${ }^{85}$ BELCH, Stanislau F. Paulus Vladimiri and his doctrine concerning international law and politics. v. 2. London, The Hague, Paris: Mouton, 1965.

${ }^{86}$ DUFOUR, Alfred. Droit international et chrétienté: des origines espagnoles aux origines polonaises du droit international. Autour du sermon De bellis justis du canoniste polonais Stanislas de Skarbimierz (1360-1431). In: DUPUY, Pierre-Marie; CHETAIL, Vincent (org.). The Roots of International Law: Liber Amicorum Peter
} 
Evidentemente, esses autores não eram parte da "Escola de Salamanca" na interpretação institucional do termo. No entanto, eles podem ter compartilhado características que os distinguiam de suas comunidades epistêmicas contemporâneas e podem assim ser mais proveitosamente vistos em um contexto compartilhado com autores de Salamanca ou México do que, por exemplo, com escritores de suas proximidades mais imediatamente locais ou regionais. O desafio para pesquisas futuras está em estabelecer um conjunto de critérios subjetivos e objetivos, bem mais detalhados do que os apresentados aqui, através de uma leitura atenta dos textos e seus contextos, que nos ajude a aproximar diferentes atores do sistema comunicativo para uma visão conjunta, apesar do fato de que eles vieram de confissões, tradições e continentes diferentes.

\section{SALAMANCA COMO UM CASO DE PRODUÇÃO GLOBAL DE CONHECIMENTO}

Por que, no entanto, uma produção "global" de conhecimento? A pesquisa sobre história global nas últimas décadas alegou que a crescente expansão das esferas de influências e das interconexões coloniais não pode simplesmente ser concebida como um processo de ideias desenvolvidas na Europa sendo disseminadas para o resto do mundo. Ela expôs as premissas eurocêntricas subjacentes às narrativas simplistas de origens europeias sendo copiadas nas periferias, ou exercendo "influência" lá. Ela nos tornou crescentemente conscientes da interconectividade de diferentes regiões do mundo, e dos profundos entrelaçamentos entre diferentes locais. Estudos especialmente do campo emergente da história do conhecimento descobriram a natureza social e comunicativa do conhecimento e a importância das traduções (culturais) e das mudanças semânticas que elas produzem.

A abordagem sugerida aqui quer levar essas afirmações a sério. Ela é baseada na premissa jurídico-teórica de que a normatividade deve ser entendida como um sistema comunicativo, uma prática cultural que pode ser observada em várias localidades, que é construída sobre condições materiais e estilos discursivos e que se transforma continuamente. Ver a Escola de Salamanca como uma prática cultural substitui, portanto, um paradigma

Haggenmacher. Leiden; Boston: Brill | Nijhoff, 2014. Disponível em: <https://doi.org/10.1163/9789004261655>. 
baseado em um entendimento europeu restrito da história da Escola como uma contribuição para o conhecimento europeu [european scholarship] - como para o trabalho de Hinojosa e de seus seguidores - ao tentar compreender a Escola como uma comunidade epistêmica e uma comunidade de prática que não pode ser limitada a um continente, mas que estava estruturalmente sem limitações geográficas. Seu escopo depende do alcance da circulação do conhecimento normativo - incluindo, é claro, conhecimento prático normativo - de qual ela consistia.

Outra importante finalidade de enquadrar nossa análise da Escola como prática comunicativa reside no fato de que o desenvolvimento de conhecimento no campo da normatividade não pode ser reduzido à história do conhecimento "erudito", sem levar a dimensão prática, bem como as práticas no sentido praxiológico, em conta. A perspectiva aqui sugerida quer superar a argumentação circular de construção da Escola como um fenômeno puramente acadêmico de acordo com padrões europeus. Como quase não existiam universidades desse tipo fora da Europa, não é surpreendente que, quando olhando através da lente dos padrões europeus, só se encontre o que parecem cópias desbotadas dos originais. Compreender a Escola como uma prática comunicativa mostra como é historicamente incorreta a imagem de uma escola solipsista atuando como um centro produtor e exportador de teorias, que comunica conhecimento para sua esfera de influência sem ser afetado pelo que, por sua vez, veio dela. Pelo contrário, esse modo revela um espaço global cheio de comunidades epistêmicas e comunidades de prática que continuamente produziram conhecimento normativo em diferentes formatos, e, assim, contribuíram para o desenvolvimento policêntrico de uma linguagem jurídico-política que não tem apenas uma dimensão - a acadêmica - e não apenas um centro, mas vários.

Pode ser mesmo possível mapear os fluxos de comunicações, os nódulos na rede, alguns maiores, outros menores. Em um mapa desse tipo, regiões e locais particulares - como, por exemplo, na Península Ibérica - podem ser revelados como a localização de importantes centros. Ele também pode mostrar onde processos similares de produção de conhecimento ocorreram em ambos os lados de uma fronteira continental ou até confessional - ou onde, por contraste, eles claramente diferiam. Talvez nós também encontremos algo como um “escolasticismo colonial” enquanto uma comunidade epistêmica claramente distinguível ${ }^{87}$.

\footnotetext{
${ }^{87}$ Isso seria diferente de tomar a configuração colonial como ponto de partida: ver, por exemplo: BEUCHOT, Mauricio. Ensayos sobre la Escolástica Hispana. Pamplona: Servicio de Publicaciones de la Universidad de Navarra, 2013; CULLETON, Alfredo S.; PICH, Roberto H. Scholastica colonialis - Reception and Development
} 
Nesse mapa, Salamanca, México e Manila podem repentinamente estar muito próximos uns aos outros, mais próximos que, por exemplo, Madrid e Milão. Em todas essas localizações, conhecimento normativo foi produzido sob condições práticas muito específicas, localizadas, e traduzidas ao contexto de cada caso individual. As afirmações normativas resultantes se tornaram parte de um vasto leque de conhecimento normativo para ser utilizado no futuro. Esse processo levou à emergência de um corpo de conhecimento normativo que fornecia ao mundo - para melhor ou pior - importantes elementos para a formação do "imperialismo jurídico", mas também para um "código universal" de legalidade ou mesmo um "direito cosmopolitano", para o qual nós também contribuímos continuamente até o presente.

\section{REFERÊNCIAS}

\section{Fontes Primárias}

AZPILCUETA, Martín de. Commentarii in tres de poenitentia distinctiones posteriores, videlicet V, VI et VII. Lugduni: Petrus Fradinus, 1569.

CANO, Melchor. De locis Theologicis, Libri Duodecim. Salamanca: Mathias Gast, 1563.

SOTO, Domingo de. De iustitia et iure. Salamanca: Andrea de Portonaris, 1556.

SUÁREZ, Francisco. Tractatus de legibus ac deo legislatore in decem libros distributis. Conimbricæ: Diego Gómez de Loureiro, 1612.

VITORIA, Francisco de. Comentario a la Ia Pars de la Summa Theologiae. In: LANGELLA, Simona. La ciencia teológica de Francisco de Vitoria y la Summa Theologiae de Santo Tomás de Aquino en el siglo XVI a la luz de textos inéditos. Salamanca: San Esteban, 2013. v.1, app., p. 262-415.

VITORIA, Francisco de. De Indis prior. In: VITORIA, Francisco de. Relectiones Theologicae XII. v. 1. Lugduni: Boyerius, 1557. (The School of Salamanca. A Digital Collection of Sources). Disponível em: $<$ https://id.salamanca.school/texts/W0013:vol1.5?format=html>.

of Baroque Scholasticism in Latin-American Countries, 16th-18th centuries: The Two First Years of a Project. Bulletin de Philosophie Médiévale, [s. l.], v. 54, p. 21-42, 2012; RESTREPO, Luis Fernando. Colonial Thought. In: NUCCETELLI, Susana; SCHUTTE, Ofelia; BUENO, Otávio (org.). A companion to Latin American philosophy. Chichester: Wiley-Blackwell, 2010. p. 36-52. 
VITORIA, Francisco de. De potestate civili. In: VITORIA, Francisco de. Relectiones Theologicae XII. v. 1. Lugduni: Boyerius, 1557. (The School of Salamanca. A Digital Collection of Sources). Disponível em: $<$ https://id.salamanca.school/texts/W0013:vol1.5?format=html>.

VITORIA, Francisco de. Disensiones del reverendo padre maestro fray Francisco de Vitoria sobre ciertos tratos de mercaderes. In: ZORROZA HUARTE, María Idoya (org.). Francisco de Vitoria. Contratos y usura. Pamplona: Ediciones Universidad de Navarra, 2006. p. 301306.

VITORIA, Francisco de. Prefacio [Preface to the edition of Aquinas' II-IIae, Paris, 1512: Claudio Chevalon.]. In: LANGELLA, Simona. La ciencia teológica de Francisco de Vitoria y la Summa Theologiae de Santo Tomás de Aquino en el siglo XVI a la luz de textos inéditos. Salamanca: San Esteban, 2013. App. i., p. 102-109.

\section{Literatura}

ABEL, Günter. Systematic Knowledge Research. Rethinking Epistemology. In: SANDKÜHLER, Hans Jörg (Ed.). Wissen: Wissenskulturen und die Kontextualität des Wissens, Frankfurt: Peter Lang, 2014. p. 17-37.

ABULAFIA, David. The discovery of mankind: Atlantic encounters in the age of Columbus. New Haven: Yale Univ. Press, 2008.

ALONSO GETINO, Luis G. El Maestro Fr. Francisco de Vitoria. Su vida, su doctrina e influencia. Madrid: Imprenta Católica, 1930.

ALONSO ROMERO, María Paz. Salamanca, escuela de juristas: estudios sobre la enseñanza del derecho en el Antiguo Régimen. Madrid: Dykinson, 2012.

ANGHIE, Antony. Imperialism, sovereignty, and the making of international law. Cambridge: Cambridge University Press, 2005.

ASTORRI, Paolo. Lutheran theology and contract law in early modern Germany (ca. 15201720). Paderborn: Brill Schöningh, 2019.

BARRETO XAVIER, Ângela; PALOMO, Federico; STUMPF, Roberta Giannubilo (org.). Monarquias ibéricas em perspectiva comparada (séculos XVI-XVIII): dinâmicas imperiais e circulação de modelos político-administrativos. Lisboa, Portugal: Imprensa de Ciências Sociais, 2018.

BARRIENTOS GARCÍA, José. La escuela de Salamanca: desarrollo y caracteres. Ciudad de Dios: Revista agustiniana, [s. l.], v. 208, n. 2-3, p. 1041-1079, 1995.

BARRIENTOS GARCÍA, José. Los Tratados "De Legibus" y "De Iustitia et Iure" en la Escuela de Salamanca de los siglos XVI y XVII. Salamanca: revista de estudios, [s. l.], n. 47, p. 371-415, 2001. 
BARRIENTOS GARCÍA, José. La teología, siglos XVI-XVII. In: RODRÍGUEZ-SAN PEDRO BEZARES, Luis Enrique (org.). Historia de la Universidad de Salamanca. v. 3/1. 1. ed. Salamanca: Ediciones Universidad de Salamanca, 2002.

BARRIENTOS GARCÍA, José. Repertorio de moral económica, 1526-1670: la Escuela de Salamanca y su proyección. 1. ed. Pamplona: Eunsa, 2011.

BARRIENTOS GARCÍA, José. La Facultad de Teología de la Universidad de Salamanca a través de los Libros de Visita de Cátedras (1560-1641). Madrid: Sindéresis, 2018.

BATAILLON, Marcel. Erasme et l'Espagne. Recherches sur l'histoire spirituelle du XVIe siècle. Paris, Bordeaux: E. Droz, 1937.

BELCH, Stanislau F. Paulus Vladimiri and his doctrine concerning international law and politics. v. 2. London, The Hague, Paris: Mouton, 1965.

BELDA PLANS, Juan. La escuela de Salamanca y la renovación de la teología en el siglo XVI. Madrid: Biblioteca de Autores Cristianos, 2000.

BELDA PLANS, Juan. Hacia una noción crítica de la "Escuela de Salamanca". Scripta theologica, [s. l.], v. 31, n. 2, p. 367-411, 1999.

BELDA PLANS, Juan. Teología práctica y escuela de Salamanca del siglo XVI. Cuadernos salmantinos de filosofía, [s. l.], n. 30, p. 461-489, 2003.

BELTRÁN DE HEREDIA, Vicente. Los manuscritos del maestro fray Francisco de Vitoria, O.P. Madrid: Santo Domingo el Real, 1928.

BERMEJO, Ignacio Jericó. ¿Escuela de Salamanca y Pensamiento hispánico?: Ante una propuesta. Salmanticensis, [s. l.], v. 59, n. 1, p. 83-114, 2012.

BEUCHOT, Mauricio. Ensayos sobre la Escolástica Hispana. Pamplona: Servicio de Publicaciones de la Universidad de Navarra, 2013.

BRAGAGNOLO, Manuela. Managing Legal Knowledge in Early Modern Times. Martín de Azpilcueta's Manual for Confessors and the Phenomenom of 'Epitomisation'. In: DUVE, Thomas; DANWERTH, Otto (org.). Knowledge of the Pragmatici: Legal and Moral Theological Literature and the Formation of Early Modern Ibero-America. Leiden: Brill | Nijhoff, 2020. p. 187-242. Disponível em: <https://doi.org/10.1163/9789004425736>.

BRAUN, Harald E.; ASTORRI, Paolo (org.). A Companion to the Spanish Scholastics. Leiden: Brill, [no prelo].

BRETT, Annabel. Sources in the Scholastic Legacy: The (re)Construction of the Ius Gentium in the Second Scholastic. In: BESSON, Samantha; D'ASPREMONT, Jean (org.). The Oxford Handbook of the Sources of International Law. Oxford; New York: Oxford University Press, 2017. p. 64-82. Disponível em: <https://doi.org/10.1093/law/9780198745365.003.0003>. 
BRUFAU PRATS, Jaime. La Escuela de Salamanca ante el descubrimiento del Nuevo Mundo. Salamanca: Editorial San Esteban, 1989.

BOUZA ALVAREZ, Fernando J.; CARDIM, Pedro; FEROS, Antonio (org.). The Iberian world 1450-1820. New York: Routledge, 2020.

BURKE, Peter. What is the history of knowledge? Cambridge: Polity, 2016.

CARABIAS TORRES, Ana María. La Escuela de Salamanca. Perspectivas de investigación. Salamanca Working Papers Series, Frankfurt am Main, n. 2015-3, 2015.

CEREZO, Prometeo. Influencia de la Escuela de Salamanca en el pensamiento universitario americano. In: RAMOS, Demetrio et al. (org.). La ética de la conquista de América. Madrid: Consejo Superior de Investigaciones Científicas, 1984. p. 551-596.

CETINA KORR, Karin. Epistemic cultures. In: RESTIVO, Sal P. (org.). Science, Technology, and Society. Oxford: Oxford University Press, 2005.

CULLETON, Alfredo S.; PICH, Roberto H. Scholastica colonialis - Reception and Development of Baroque Scholasticism in Latin-American Countries, 16th-18th centuries: The Two First Years of a Project. Bulletin de Philosophie Médiévale, [s. l.], v. 54, p. 21-42, 2012.

DASTON, Lorraine. The History of Science and the History of Knowledge. Know, [s. l.], v. 1, n. 1, p. 131-154, 2017. Disponível em: <https://doi.org/10.1086/691678>.

DECOCK, Wim. From Law to Paradise: Confessional Catholicism and Legal Scholarship. Rechtsgeschichte - Legal History, $[s$. l. $]$, n. 18, p. 12-43, 2011. Disponível em: <https://doi.org/10.12946/rg18/012-034>.

DECOCK, Wim. Theologians and Contract Law: The Moral Transformation of the Ius Commune (ca. 1500-1650). Leiden: Brill Nijhoff, 2012.

DECOCK, Wim; BIRR, Christiane. Recht und Moral in der Scholastik der Frühen Neuzeit 1500-1750. Berlin; Boston: De Gruyter, 2016. Disponível em: $<$ https://doi.org/10.1515/9783110379686>.

DUFOUR, Alfred. Droit international et chrétienté: des origines espagnoles aux origines polonaises du droit international. Autour du sermon De bellis justis du canoniste polonais Stanislas de Skarbimierz (1360-1431). In: DUPUY, Pierre-Marie; CHETAIL, Vincent (org.). The Roots of International Law: Liber Amicorum Peter Haggenmacher. Leiden; Boston: Brill | Nijhoff, 2014. Disponível em: <https://doi.org/10.1163/9789004261655>.

DUVE, Thomas. ¿'La mayor burla del mundo'? Francisco de Vitoria y el dominium del Papa sobre los bienes de los pobres. In: CRUZ CRUZ, Juan (org.). Ley y domino en Francisco de Vitoria. Pamplona: EUNSA, 2008. p. 93-106. 
DUVE, Thomas. Von der Europäischen Rechtsgeschichte zu einer Rechtsgeschichte Europas in globalhistorischer Perspektive. Rechtsgeschichte - Legal History, [s. l.], n. 20, p. 71, 2012. Disponível em: <https://doi.org/10.12946/rg20/018-071>.

DUVE, Thomas. Salamanca in Amerika. Zeitschrift der Savigny-Stiftung für Rechtsgeschichte: Germanistische Abteilung, [s. l.], v. 132, n. 1, p. 116-151, 2015. Disponível em: <https://doi.org/10.7767/zrgga-2015-0108>.

DUVE, Thomas. Was ist \Multinormativität $<$ - Einführende Bemerkungen. Rechtsgeschichte - Legal History, [s. l.], n. 25, p. 88-101, 2017. Disponível em: <https://doi.org/10.12946/rg25/088-101>.

DUVE, Thomas. Global Legal History: Setting Europe in Perspective. In: PIHLAJAMÄKI, Heikki; DUBBER, Markus D.; GODFREY, Mark (org.). The Oxford Handbook of European Legal History. Oxford; New York: Oxford University Press, 2018. p. 115-140. Disponível em: 〈https://doi.org/10.1093/oxfordhb/9780198785521.013.5>.

DUVE, Thomas. La Escuela de Salamanca: ¿un caso de producción global de conocimiento? consideraciones introductorias desde una perspectiva histórico-jurídica y de la historia del conocimiento. The School of Salamanca Working Paper Series, Frankfurt am Main, n. 2018$2,2018$.

DUVE, Thomas. Legal traditions: A dialogue between comparative law and comparative legal history. Comparative Legal History, [s. l.], v. 6, n. 1, p. 15-33, 2018. Disponível em: <https://doi.org/10.1080/2049677X.2018.1469271>.

DUVE, Thomas. Rechtsgeschichte und Rechtsräume: wie weit reicht die Schule von Salamanca? In: LUTS-SOOTAK, Marju; SCHÄFER, Frank L. (org.). Recht und Wirtschaft in Stadt und Land - Law and Economics in Urban and Rural Environment. Neunter Rechtshistorikertag im Ostseeraum/9th Conference in Legal History in the Baltic Sea Area 16.-20. Mai 2018 in Tallinn, Sagadi und Tartu, Estland/ in Tallinn, Sagadi and Tartu, Estonia. Bern: Peter Lang, 2020. p. 51-72. Disponível em: <https://doi.org/10.3726/b16496>.

DUVE, Thomas; DANWERTH, Otto (org.). Knowledge of the Pragmatici: Legal and Moral Theological Literature and the Formation of Early Modern Ibero-America. Leiden; Boston: Brill | Nijhoff, 2020. Disponível em: <https://doi.org/10.1163/9789004425736>.

DUVE, Thomas. Pragmatic Normative Literature and the Production of Normative Knowledge in the Early Modern Iberian Empires (16th-17th Centuries). In: DUVE, Thomas; DANWERTH, Otto (org.). Knowledge of the Pragmatici: Legal and Moral Theological Literature and the Formation of Early Modern Ibero-America. Leiden: Brill | Nijhoff, 2020. p. 1-39. Disponível em: <https://doi.org/10.1163/9789004425736_002〉.

DUVE, Thomas. The School of Salamanca: a legal historical perspective. In: BRAUN, Harald E.; ASTORRI, Paolo (org.). A Companion to the Spanish Scholastics. Leiden: Brill, [no prelo].

EGÍO GARCÍA, José Luis; BIRR, Christiane U. Alonso de Cartagena y Juan López de Palacios Rubios. Dilemas suscitados por las primeras conquistas atlánticas en dos juristas 
salmantinos (1436-1512). Azafea: Revista de Filosofía, [s. l.], v. 20, p. 9-36, 2018. Disponível em: 〈https://doi.org/10.14201/17705>.

EGÍO GARCÍA, José Luis; BIRR, Christiane. Before Vitoria: Expansion into Heathen, Empty or Disputed Lands in Late-Mediaeval Salamanca Writings and Early 16th-Century Juridical Treatises. In: TELLKAMP, Jörg Alejandro (org.). A Companion to Early Modern Spanish Imperial Political and Social Thought. Leiden; Boston: Brill, 2020. p. 53-77.

FERNÁNDEZ-ARMESTO, Felipe. Before Columbus: exploration and colonization from the Mediterranean to the Atlantic 1229-1492. 3. ed. Philadelphia, Pa: University of Pennsylvania Press, 1994.

FOLGADO, Avelino. Los tratados De legibus y De iustitia et iure en los autores españoles del siglo XVI y primera mitad del XVII. La Ciudad de Dios, [s. l.], v. 72, n. 3, p. 275-302, 1959.

GONZÁLEZ POLVILLO, Antonio. El gobierno de los otros: confesión y control de la conciencia en la España moderna. Sevilla: Universidad de Sevilla, Secretariado de Publicaciones, 2010.

GORDLEY, James. The philosophical origins of modern contract doctrine. Oxford; New York: Oxford University Press; Clarendon Press, 1991.

GRABMANN, Martin. Die Disputationes metaphysicae des Franz Suarez in ihrer methodischen Eigenart und Fortwirkung. In: SIX, Karl et al. (org.). P. Franz Suarez S.J.: Gedenkblätter zu seinem dreihundertjährigen Todestag (25. September 1917). Beiträge zur Philosophie des P. Suarez. Innsbruck: Tyrolia, 1917. p. 29-73.

GRICE-HUTCHINSON, Marjorie. El concepto de la Escuela de Salamanca: sus orígenes y su desarrollo. Revista de Historia Económica, [s. l.], v. 7, n. S1, p. 21-26, 1989. Disponível em: <https://doi.org/10.1017/S0212610900001798>.

HESPANHA, António. Southern Europe (Italy, Iberian Peninsula, France). In: PIHLAJAMÄKI, Heikki; DUBBER, Markus D.; GODFREY, Mark (org.). The Oxford Handbook of European Legal History. Oxford: Oxford University Press, 2018. p. 332-356. Disponível em: <https://doi.org/10.1093/oxfordhb/9780198785521.013.17〉.

HINOJOSA Y NAVEROS, Eduardo de. Discursos leídos ante la Real Academia de la Historia en la recepción pública de D. Eduardo de Hinojosa el día 10 de marzo de 1889. Madrid: Huérfanos, 1889.

JANSEN, Nils. Theologie, Philosophie und Jurisprudenz in der spätscholastischen Lehre von der Restitution. Außer-vertragliche Ausgleichsansprüche im frühneuzeitlichen Naturrechtsdiskurs. Tübingen: Mohr Siebeck, 2013.

KOHLER, Josef. Die spanischen Naturrechtslehrer des 16. und 17. Jahrhunderts. Archiv für Rechts- und Wirtschaftsphilosophie, [s. l.], v. 10, n. 3, p. 235-263, 1917.

KOSKENNIEMI, Martti. The gentle civilizer of nations: the rise and fall of international law, 1870-1960. Cambridge: Cambridge University Press, 2002. 
KOSKENNIEMI, Martti. Empire and International Law: The Real Spanish Contribution. University of Toronto Law Journal, [s. l.], v. 61, n. 1, p. 1-36, 2011. Disponível em: <https://doi.org/10.1353/tlj.2011.0008>.

KOSKENNIEMI, Martti. Vitoria and Us: Thoughts on Critical Histories of International Law. Rechtsgeschichte - Legal History, [s. l.], n. 22, p. 119-138, 2014. Disponível em: <https://doi.org/10.12946/rg22/119-138>.

LALINDE ABADIA, Jesús. Anotaciones historicistas al iusprivatismo de la segunda escolástica. In: GROSSI, Paolo (org.). La Seconda scolastica nella formazione del diritto privato moderno. Incontro di studio, Firenze 16-19 ottobre 1972. Milano: Giuffrè, 1973. p. 303-375.

LALINDE ABADIA, Jesús. Una ideología para un sistema (La simbiosis histórica entre el iusnaturalismo castellano y la Monarquía Universal). Quaderni fiorentini per la storia del pensiero giuridico moderno, [s. l.], v. 8, p. 62-156, 1979.

LANGELLA, Simona. La ciencia teológica de Francisco de Vitoria y la Summa Theologiae de Santo Tomás de Aquino en el siglo XVI a la luz de textos inéditos. Salamanca: San Esteban, 2013.

MAHONEY, John. The making of moral theology: a study of the Roman Catholic tradition. Reprinted ed. Oxford; New York: Clarendon press, 1989.

MANDRELLA, Isabelle. Der Dekalog als Systematisierungsschlüssel angewandter Ethik im 13. und 14. Jahr-hundert. In: KORFF, Wilhelm; VOGT, Markus (org.). Gliederungssysteme angewandter Ethik. Ein Handbuch. Nach einem Projekt von Wilhelm Korff. Freiburg; Basel; Wien: Herder, 2016. p. 228-255.

MARCOCCI, Giuseppe. Conscience and Empire: Politics and Moral Theology in the Early Modern Portuguese World. Journal of Early Modern History, vol. 18, n. 5, p. 473-494, 2014.

MARTÍN GÓMEZ, María. Francisco de Vitoria y la Escuela Ibérica de la Paz. Revista Portuguesa de Filosofia, $[s$. l. $]$, v. 75, n. 2, p. 861-890, 2019. Disponível em: <https://doi.org/10.17990/RPF/2019_75_2_0861>.

MARTÍNEZ NEIRA, Manuel; RAMÍREZ JÉREZ, Pablo. Hinojosa en la Real Academia de Ciencias Morales y Políticas. Madrid: Dykinson, 2018.

MARTÍNEZ PEÑAS, Leandro. El confesor del rey en el Antiguo Régimen. Madrid: Editorial Complutense, 2006.

MAYES, Benjamin T. G. Counsel and conscience: Lutheran casuistry and moral reasoning after the Reformation. Göttingen: Vandenhoeck \& Ruprecht, 2011.

MÖLLERS, Christoph. Die Möglichkeit der Normen. Über eine Praxis jenseits von Moralität und Kausalität. Berlin: Suhrkamp, 2015. 
MOUTIN, Osvaldo Rodolfo. Legislar en la América hispánica en la temprana edad moderna: procesos y características de la producción de los Decretos del Tercer Concilio Provincial Mexicano (1585). Frankfurt am Main: Max Planck Institute for European Legal History, 2016. (Global perspectives on legal history, v. 4).

MULDOON, James (org.). Bridging the medieval-modern divide: medieval themes in the world of the reformation. Farnham: Ashgate, 2013.

MÜLLER-WILLE, Staffan; REINHARDT, Carsten; SOMMER, Marianne. Wissenschaftsgeschichte und Wissensgeschichte. In: MÜLLER-WILLE, Staffan et al. (org.). Handbuch Wissensgeschichte. Stuttgart: J. B. Metzler, 2017. p. 02-18.

MÜLLER, Sigrid. Die Bedeutung des Dekalogs für die Entwicklung der neuzeitlichen Moraltheologie im Zeichen der Kasuistik. In: KORFF, Wilhelm; VOGT, Markus (org.). Gliederungssysteme angewandter Ethik. Ein Handbuch. Nach einem Projekt von Wilhelm Korff. Freiburg; Basel; Wien: Herder, 2016. p. 256-283.

NEUMANN, Birigt. Kulturelles Wissen. In: NÜNNING, Ansgar (org.). Metzler Lexikon Literatur- und Kulturtheorie: Ansätze-Personen-Grundbegriffe. 5. ed. Stuttgart; Weimar: Springer, 2013.

NYS, Ernest. Le droit de la guerre et les précurseurs de Grotius. Bruxelles; Leipzig; Londres; New York; Paris: Librairie Européenne C. Muquardt, Merzbach et Falk; Trübner \& Co; Durand et Pedone Lauriel, 1882.

O'BANION, Patrick J. The Sacrament of Penance and Religious Life in Golden Age Spain. University Park (PA): Pennsylvania State University Press, 2012.

OLMEDO BERNAL, Santiago. El dominio del Atlántico en la baja Edad Media: los títulos jurídicos de la expansión peninsular hasta el Tratado de Tordesillas. Valladolid: Sociedad V Centenario del Tratado de Tordesillas, 1995.

PAGDEN, Anthony. The Christian Tradition. In: BUCHANAN, Allen E.; MOORE, Margaret (org.). States, nations, and borders: the ethics of making boundaries. Cambridge; New York: Cambridge University Press, 2003. p. 103-126.

PENA GONZÁLEZ, Miguel Anxo. Aproximación bibliográfica a la(s) "Escuela(s) de Salamanca”. Salamanca: Universidad Pontifica de Salamanca, 2008.

PEREÑA, Luciano. La Escuela de Salamanca y la duda indiana. In: RAMOS, Demetrio et al. (org.). La ética de la conquista de América. Madrid: Consejo Superior de Investigaciones Científicas, 1984. p. 291-344.

PEREÑA, Luciano. La Escuela de Salamanca: proceso a la conquista de América. Salamanca: Caja de Ahorros y Monte de Piedad de Salamanca, 1986.

PEREÑA, Luciano. La Escuela de Salamanca, notas de identidad. In: GÓMEZ CAMACHO, Francisco; ROBLEDO, Ricardo (org.). El pensamiento económico en la Escuela de Salamanca: una visión multidisciplinar. Seminarios celebrados en Salamanca en 1992, 1993, 
y 1995 organizados por la Fundación Duques de Soria y dirigidos por el Profesor Ernest Lluch. Salamanca: Ediciones Universidad Salamanca, 1998. p. 43-64.

PÉREZ VOITURIEZ, Antonio. Problemas jurídicos internacionales de la conquista de Canarias. Las Palmas de Gran Canaria: Universidad de La Laguna, 1958.

POGNER, Karl-Heinz. Textproduktion in Diskursgemeinschaften. In: JAKOBS, Eva-Maria; KNORR, Dagmar; POGNER, Karl-Heinz (org.). Textproduktion: HyperText, Text, KonText. Frankfurt am Main: P. Lang, 1999. p. 145-158.

QUANTIN, Pierre Michaud. A propos des premières Summae confessorum: Théologie et droit canonique. Recherches de théologie ancienne et médiévale, [s. l.], v. 26, p. 264-306, 1959.

QUANTIN, Jean-Louis. Catholic Moral Theology, 1550-1800. In: LEHNER, Ulrich L.; MULLER, Richard A.; ROEBER, A. G. (org.). The Oxford Handbook of Early Modern Theology, 1600-1800. Oxford; New York: Oxford University Press, 2016. p. 119-134.

RAMÍREZ SANTOS, Celia Alejandra; EGÍO, José Luis. Conceptos, autores, instituciones: revisión crítica de la investigación reciente sobre la Escuela de Salamanca (2008-19) y bibliografía multidisciplinar (con Prefacio de Thomas Duve). Madrid: Editorial Dykinson, 2020.

RAMOS, Demetrio (org.). Francisco de Vitoria y la Escuela de Salamanca: La ética en la Conquista de América. Madrid: Consejo Superior de Investigaciones Científicas, 1984.

RASILLA DEL MORAL, Ignacio de la. In the Shadow of Vitoria: A History of International Law in Spain (1770-1953). Leiden: Brill Nijhoff, 2017.

RAUSCHENBACH, Sina; WINDLER, Christian (org.). Reforming early modern monarchies: the Castilian Arbitristas in Comparative European perspectives. Wiesbaden: Harrassowitz, 2016.

REIBSTEIN, Ernst. Johannes Althusius als Fortsetzer der Schule von Salamanca. Untersuchungen zur Ideengeschichte des Rechtsstaates und zur altprotestantischen Naturrechtslehre. Karlsruhe: C. F. Müller, 1955.

RENN, Jürgen (Ed.). The Globalization of Knowledge in History. Berlin: Edition Open Access, 2012. Disponível em: 〈http://edition-open-access.de/studies/1/index.html〉.

RENN, Jürgen; HYMAN, Malcolm H. The Globalization of Knowledge in History: An Introduction. in: RENN, Jürgen (Ed.). The Globalization of Knowledge in History. Berlin: Edition Open Access, 2012. p. 15-44. Disponível em: <http://www.edition-openaccess.de/media/studies/1/5/Studies1ch1.pdf>.

RENN, Jürgen. The Globalization of Knowledge in History and its Normative Challenges. Rechtsgeschichte - Legal History, vol. 22, p. 52-60, 2014. Disponível em: https://doi.org/10.12946/rg22/052-060 
RENN, Jürgen. From the History of Science to the History of Knowledge - and Back. Centaurus, vol. 57, n. 1, 2015, p. 37-53. Disponível em: https://doi.org/10.1111/16000498.12075

RESTREPO, Luis Fernando. Colonial Thought. In: NUCCETELLI, Susana; SCHUTTE, Ofelia; BUENO, Otávio (org.). A companion to Latin American philosophy. Chichester: Wiley-Blackwell, 2010. p. 36-52.

RODRÍGUEZ-SAN PEDRO BEZARES, Luis Enrique; POLO RODRÍGUEZ, Juan Luis (org.). La Universidad de Salamanca y sus confluencias americanas. Salamanca: Universidad de Salamanca, 2008.

RODRÍGUEZ-SAN PEDRO BEZARES, Luis E.; POLO RODRÍGUEZ, Juan Luis. Bibliografía sobre la Universidad de Salamanca (1800-2007). In: RODRÍGUEZ-SAN PEDRO BEZARES, Luis Enrique; POLO RODRÍGUEZ, Juan Luis (org.). Historia de la Universidad de Salamanca. Vestigios y entramados. v. 4. 1. ed. Salamanca: Ediciones Universidad de Salamanca, 2002. p. 639-836.

SCARFI, Juan Pablo. The hidden history of international law in the Americas: empire and legal networks. New York, NY: Oxford University Press, 2017.

SCATTOLA, Merio. 'Notitia naturalis de Deo et de morum gubernatione'. Die Naturrechtslehre Philipp Melanchthons und ihre Wirkung im 16. Jahrhundert. In: BAUER, Barbara (org.). Melanchthon und die Marburger Professoren. Marburg: Universitätsbibliothek Marburg, 1999. p. 865-882.

SCATTOLA, Merio. Johannes Althusius und das Naturrecht des 16. Jahrhunderts. In: CARNEY, Frederick S.; SCHILLING, Heinz; WYDUCKEL, Dieter (org.). Jurisprudenz, Politische Theorie und Politische Theologie. Beiträge des Herborner Symposions zum 400. Jahrestag der Politica des Johannes Althusius (1603-2003). Berlin: Duncker \& Humblot, 2004. p. 371-396.

SCATTOLA, Merio. Widerstand und Naturrecht im Umkreis von Philipp Melanchthon. In: SCHORN-SCHÜTTE, Luise (org.). Das Interim 1548/50: Herrschaftskrise und Glaubenskonflikt. Gütersloh: Gütersloher Verlagshaus, 2005. p. 459-487.

SCATTOLA, Merio. Krieg des Wissens, Wissen des Krieges: Konflikt, Erfahrung und System der literarischen Gattungen am Beginn der Frühen Neuzeit. Padova: Unipress, 2006.

SCATTOLA, Merio. Domingo de Soto e la fondazione della scuola di Salamanca. Veritas, Porto Alegre, v. 54, n. 3, p. 52-70, 2009. Disponível em: <https://doi.org/10.15448/19846746.2009.3.6416>.

SCATTOLA, Merio. Das Ganze und die Teile. Menschheit und Völker in der naturrechtlichen Kriegslehre von Francisco de Vitoria. In: BRIESKORN, Norbert; STIENING, Gideon (org.). Francisco de Vitorias "De Indis" in interdisziplinärer Perspektive. Stuttgart: FrommannHolzboog, 2011. 
SCATTOLA, Merio. Die Systematik des Natur- und Völkerrechts bei Francisco de Vitoria. In: BUNGE, Kirstin; SPINDLER, Anselm; WAGNER, Andreas (org.). Die Normativität des Rechts bei Francisco de Vitoria. Stuttgart: Frommann-Holzboog, 2011. p. 351-391.

SCHMUTZ, Jacob. From Theology to Philosophy: The Changing Status of the Summa Theologiae, 1500-2000. In: HAUSE, Jeffrey (org.). Aquinas's Summa Theologiae: A Critical Guide. Cambridge; New York: Cambridge University Press, 2018. p. 221-241. Disponível em: 〈https://doi.org/10.1017/9781316271490>.

SCHÜSSLER, Rudolf. Meinungspluralismus in Moraltheologie und Kasuistik - seine Grundlegung im Barock. In: KORFF, Wilhelm; VOGT, Markus (org.). Gliederungssysteme angewandter Ethik. Ein Handbuch. Nach einem Projekt von Wilhelm Korff. Freiburg; Basel; Wien: Herder, 2016. p. 284-307.

SCOTT, James Brown. The Catholic Conception of International Law. Francisco de Vitoria, Founder of the Modern Law of Nations. Francisco Suarez, Founder of the Modern Philosophy of Law in General and in Particular of the Laws of Nations. A Critical Examination and a Justified Appreciation. Washington D. C.: Georgetown University Press, 1934.

SCOTT, James Brown. The Spanish Origin of International Law. Francisco de Vitoria and his Law of Nations. Oxford: Clarendon Press, 1934.

SECORD, James A. Knowledge in Transit. Isis, [s. l.], v. 95, n. 4, p. 654-672, 2004. Disponível em: <https://doi.org/10.1086/430657>.

SOSA MAYOR, Igor. El noble atribulado: nobleza y teología moral en la Castilla moderna (1550-1650). Madrid: Marcial Pons, 2018.

TAMM, Ditlev. Rechtswissenschaft im Dienste der Theologie. Zur Stellung der Rechtswissenschaft an den nordischen Universitäten im 17. Jahrhundert. In: DÜBECK, Inger et al. (org.). Med lov skal land bygges og andre retshistoriske afhandlinger. København: Djøf, 1989. p. 185-195.

TELLKAMP, Jörg A. Vitorias Weg zu den legitimen Titeln der Eroberung Amerikas. In: BUNGE, Kirstin; SPINDLER, Anselm; WAGNER, Andreas (org.). Die Normativität des Rechts bei Francisco de Vitoria. Stuttgart: Frommann-Holzboog, 2011. p. 147-170.

TELLKAMP, Jörg Alejandro (org.). A Companion to Early Modern Spanish Imperial Political and Social Thought. Leiden; Boston: Brill, 2020.

THEINER, Johann. Die Entwicklung der Moraltheologie zur eigenständigen Disziplin. Regensburg: Friedrich Pustet, 1970.

THIEME, Hans. Natürliches Privatrecht und Spätscholastik. Zeitschrift der Savigny-Stiftung für Rechtsgeschichte. Germanistische Abteilung, [s. l.], v. 70, n. 1, p. 230-266, 1953. Disponível em: <https://doi.org/10.7767/zrgga.1953.70.1.230>.

VEREECKE, Louis. Storia della teologia morale moderna. v. 2. Roma: Academia Alfonsiana, 1973. 
VIDAL, Marciano. Historia de la teología moral: La moral en la edad moderna (s. XV-XVI). T. 4 (Humanismo y Reforma). v. 1. Madrid: Perpetuo Socorro, 2012.

VILLAVERDE RICO, María José; CASTILLA URBANO, Francisco (org.). La sombra de la leyenda negra. Madrid: Tecnos, 2016.

WAGNER, Andreas. Zum Verhältnis von Völkerrecht und Rechtsbegriff bei Francisco de Vitoria. In: BUNGE, Kirstin; SPINDLER, Anselm; WAGNER, Andreas (org.). Die Normativität des Rechts bei Francisco de Vitoria. Stuttgart: Frommann-Holzboog, 2011. p. 255-286.

WEHLING, Peter. Wissensregime. In: SCHÜTZEICHEL, Rainer (org.). Handbuch Wissenssoziologie und Wissensforschung. Konstanz: UVK, 2007. p. 704-712

WHITE, James Boyd. Legal Knowledge. Harvard Law Review, vol. 115, n. 5, 2002, p. 13961431. Disponível em: <https://doi.org/10.2307/1342550>.

ZORROZA HUARTE, María Idoya (org.). Francisco de Vitoria. Contratos y usura. Pamplona: Ediciones Universidad de Navarra, 2006.

ZORROZA HUARTE, María Idoya. Hacia una delimitación de la Escuela de Salamanca. Revista Empresa y Humanismo, [s. l.], v. XVI, n. 1, p. 53-72, 2013.

\section{DADOS DA PUBLICAÇÃ̃O}

Categoria: artigo de autor convidado.

Recebido em: 20/08/2021.

Aceito em: 24/08/2021. 